\begin{tabular}{|c|c|c|}
\hline $\begin{array}{l}\text { FATIH } \\
\text { SULTAN } \\
\text { MEHMET } \\
\text { VAKIF UNIVERSITESI } \\
2010\end{array}$ & $\begin{array}{l}\text { FSM İlmî Araştırmalar Insan ve Toplum Bilimleri Dergisi } \\
\text { FSM Scholarly Studies Journal of Humanities and Social Sciences } \\
\text { Sayı/Number } 14 \text { Yıl/Year } 2019 \text { Güz/Autumn } \\
\text { (c)2019 Fatih Sultan Mehmet Vakıf Üniversitesi }\end{array}$ & 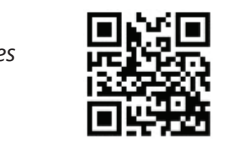 \\
\hline DOI: 10.16947/fsmia.667309 & http://dergipark.org.tr/fsmia & http://dergi.fsm.edu.tr \\
\hline Arasstırma Makalesi / Research Article & Gelis Tarihi / Received: 12.09.2019 Kabul Tarihi / Accepted: 24.10.2019 & FSMIAD, 2019; (14): 259-296 \\
\hline
\end{tabular}

\title{
Mimarlık Öğrencilerinin Çoklu Zeka Alanlarının İncelenmesi ${ }^{*}$
}

\author{
Zahide Fatma Kıllıoğlu* \\ İbrahim Numan ${ }^{* *}$ \\ Fehmi Kızıl ${ }^{\star \star * \star}$
}

\section{$\ddot{O} z$}

Bu çalışmada Mimarlık bölümlerindeki öğrencilerin çoklu zeka alanları ve çoklu zeka alanlarının cinsiyete göre nasıl farklılaştığını araştırmak amaçlanmıştır. Bu amaçla Branton Shearer'ın geliştirdiği Çoklu Zeka Alanları Gelişimsel Değerlendirme Ölçeği (MIDAS), veri toplama aracı olarak kullanılmıştır. Araştırmanın örneklemini 2017-2018 öğretim yılında Fatih Sultan Mehmet Vakıf Üniversitesi, Yıldız Teknik Üniversitesi ve Mimar Sinan Güzel Sanatlar Üniversitesi Mimarlık bölümlerinde sirasıyla Mimari Anlatım Dili, Mimari Anlatım Teknikleri ve Mimari Teknik Resim derslerini alan toplam 279 öğrenci oluşturmaktadır. Elde edilen sonuçlara göre öğrencilerin sekiz farklı zeka türünden en baskın olan ilk üç zeka alanının sırasıyla sosyal, içsel ve matematiksel zeka

* $\quad$ Bu makale, Çoklu Zeka Kuramının Mimari Anlatım Dili Eğitiminde Kullanımına Yönelik Model Önerisi adlı doktora tezinden üretilmiştir.

** Doktora Öğrencisi, Fatih Sultan Mehmet Vakıf Üniversitesi Lisansüstü Eğitim Enstitüsü, İstanbul/Türkiye, z.killioglu@stu.fsm.edu.tr, zafersan@gmail.com, orcid.org/0000-0001-61738912

*** Prof. Dr., Fatih Sultan Mehmet Vakıf Üniversitesi Mimarlık ve Tasarım Fakültesi Mimarlık Bölümü, İstanbul/Türkiye, inuman@fsm.edu.tr , orcid.org/0000-0002-2785-7536

**** Prof. Dr., Fatih Sultan Mehmet Vakıf Üniversitesi Mimarlık ve Tasarım Fakültesi Mimarlık Bölümü, İstanbul/Türkiye, fkizil@fsm.edu.tr, orcid.org/0000-0002-0093-9347 
olduğu ortaya çıkmıştır. Ayrıca mimarlık öğrencilerinin çoklu zeka alanlarının cinsiyete göre de değişiklikler gösterdiği ortaya çıkmıştır.

Anahtar Kelimeler: Mimarlık öğrencileri, çoklu zeka.

\title{
Investigation of Multiple Intelligences Fields of Architecture Students
}

\begin{abstract}
This study aimed to investigate the multiple intelligence fields of architecture students and how the multiple intelligence areas differ according to gender. For this purpose, Multiple Intelligence Developmental Assessment Scale (MIDAS) developed by Branton Shearer was used as a data collection tool. The sampling of the study consists of 279 students who took Architectural Communication Skills, Architectural Expression Techniques and Professional Technical Drawing courses in Architecture departments of Fatih Sultan Mehmet Foundation University, Y1ldız Technical University and Mimar Sinan Fine Arts University in 2017-2018 academic year. The results showed that the most dominant 3 intelligence areas out of 8 different intelligence types of the students are as follows: social, internal and mathematical intelligence. In addition, it has been revealed that the multiple intelligence fields of architecture students vary according to gender.
\end{abstract}

Keywords: Architecture students, multiple intelligences. 


\section{Giriş}

Klasik psikometrik anlayışa göre zeka, kişinin doğuştan getirdiği bir nitelik ya da yeti olarak tanımlanır' ${ }^{1}$. Çoklu zeka kuramını geliştiren Howard Gardner'a ${ }^{2}$ göre ise zeka, bir ya da birden fazla kültürel zeminde sorun çözme veya ürün ortaya koyma becerisidir.

Dünyada var olan bilgi farklı içeriklere sahip olduğundan, insanlar da farklı zekalara sahiptir ${ }^{3}$. Sahip olunan zeka alanlarının değişmesiyle birlikte bireylerin öğrenme, problem çözme ve iletişim kurma yöntemleri de değişmektedir ${ }^{4}$ ${ }^{5}$. Çoklu Zeka Kuramı, zekayı ölçerek bireyleri sınıflandırmak ve gelişmelerini sınırlandırmak yerine, bireylerin yeteneklerini ortaya çıkararak onları geliştirmelerini, eğitimcilerin de bu yönde değerlendirme yöntemleri ve farklı programlar oluşturmalarını sağlar. Birçok ülkede bulunan Çoklu Zeka okullarıyla bunun başarılabileceği de görülmektedir ${ }^{6}$. Gelişmiş ülkelerde bireye sayısız seçenek ve müfredat dışı etkinlik sunulmasıyla, zaman, heves ve belli düzeyde refah olduğunda zekaların tümünün gelişmesi sağlanabilmektedir?

Gardner, ilk kez 1983'te yayımlanan "Frames Of Mind (Zihin Çerçeveleri)" adlı eserinde yedi farklı zeka alanını tanımlamıştır. Her zaman daha fazla zeka alanlarının olabileceğine de dikkat çekmiş, 1999 yılında yayımlanan "Intelligence Reframed (Yapılandırılmıs Zeka)" adlı eserinde sekizinci bir zeka alanı ekleyerek çoklu zeka kuramını yeniden tanımlamıştır'. Gardner ${ }^{10}$, insanın en temel varoluş problemlerine kafa yorma eğilimine dayandığını düşündüğü zeka türü adayı olan varoluşsal zekayı ise derin varoluş konularıyla özellikle ilgilenen be-

1 Howard Gardner, Çoklu Zeka Yeni Ufuklar, Optimist Yayınları, 2013, s.17.

2 Howard Gardner, Çoklu Zeka Kuramı: Zihin Çerçeveleri, çeviri Ebru Kılıç, Alfa Yayınları, 2010, s. xi.

3 Gardner, a.g.e., Çoklu Zeka Kuramı: Zihin Çerçeveleri, s. xxvi.

4 Howard Gardner, The Unschooled Mind: How Children Think\&How Schools Should Teach, New York, Basic Books Published, 1991, s.11.

5 Fatma Susar Kırmızı, "İlkögretim 4. Sınıf Türkçe Öğretiminde Çoklu Zeka Kuramına Daya$l_{1}$ İşbirlikli Öğrenme Yönteminin Erişi, Tutumlar, Öğrenme Stratejileri ve Çoklu Zeka Alanları Üzerindeki Etkileri”, (Yayımlanmamış Doktora Tezi), Dokuz Eylül Üniversitesi, Eğitim Bilimleri Enstitüsü, İzmir, 2006, s.5.

6 Mustafa Zülküf Altan, "Çoklu Zeka Kuramı ve Değerler Eğitimi”, Pegem Eğitim ve Öğretim Dergisi, cilt 1, say1 4, 2011, s.57.

7 Gardner, a.g.e., Çoklu Zeka Kuramı: Zihin Çerçeveleri, s.505.

8 Gardner, a.g.e., Çoklu Zeka Kuramı: Zihin Çerçeveleri, s. xi.

9 Ahmet Saban, Çoklu Zeka Kuramı ve Türk Eğitim Sistemine Yansıması, 6.bs., Ankara, Nobel Yayın, 2010, s.11.

10 Gardner, a.g.e., Çoklu Zeka Yeni Ufuklar, s.33. 
yin kısımlarına yönelik delil eksikliği nedeniyle bir zeka türü olarak ilan etmekte tereddüt etmiştir.

Aşağıda sekiz zeka türünün özellikleri kısaca açıklanmıştır.

Müziksel - ritmik zeka: Duyguların aktarımında müziği bir araç olarak kullanan insanlardaki müzikal güce işaret eder. Bu zekası güçlü olan bireyler en kolay ritim, melodi ve müzikle öğrenirler ${ }^{11}$.

Bedensel - kinestetik zeka: Bu zeka alanı, fiziksel dünyamızda varolmam1zın ve dış dünyayı kavramamızın temelinde yatmaktadır. Gardner'a göre kinestetik altıncı duyumuzdur. Nazikçe hareket edebilme kabiliyetiyle, diğer insanların ve nesnelerin hareketlerini doğrudan kavramayı içerir ${ }^{12}$.

Mantıksal - matematiksel zeka: Bir matematikçi, muhasebeci veya istatistikçi gibi sayıları etkili bir şekilde kullanma ve bir bilim adamı, bilgisayar programcısı veya bir mantık uzmanı gibi iyi düşünme kapasitesini ifade eder ${ }^{13}$.

Görsel - uzamsal zeka: Görsel dünyanın doğru biçimde algılanması, başlangıçtaki alg1 üzerinde değişim ve dönüşümlerin yapılabilmesi, görsel deneyimin fiziksel uyarıcının yokluğunda dahi yeniden üretilebilmesi olarak tanımlanır ${ }^{14}$.

Sözel - dilsel zeka: $\mathrm{Bu}$ zeka, kişinin sözcüklerle düşünme ve dili karmaşık anlamları ifade etmek ve anlamak için kullanma kabiliyetini ifade eder ${ }^{15}$.

Kişilerarası - sosyal zeka: Bu zeka insanlarla ilişki kurma, onları anlama, güdüleme ve davranışlarını yorumlama yeteneklerini içerir ${ }^{16}$.

Özedönük - içsel zeka: Bu zeka alanı bir kişinin kendisini objektif olarak değerlendirmesi, sahip olduğu duygu, ihtiyaç ve amaçların farkında olması, kendisini denetim altında tutabilmesi ve kendisine güvenmesi gibi yetenekleri içerir ${ }^{17}$.

11 Ayten İflazoğlu, "Çoklu Zeka Kuramı Destekli Kubaşık Öğrenme Yönteminin İlköğretim 5. Sınıf Öğrencilerinin Fen Bilgisi Dersindeki Akademik Başarıları ve Tutumlarına Etkisi”, (Yayımlanmamış Doktora Tezi), Çukurova Üniversitesi, Adana, 2003, s.23.

12 Özge Çongur Yeşilkaya, "Müzik Öğretiminde Çoklu Zeka Kuramı Uygulamalarına Yönelik Model Araştırma”, (Yayımlanmamış Doktora Tezi), Gazi Üniversitesi, Ankara, 2007, s.23.

13 Thomas Armstrong, Multiple Intelligences In The Classroom, Alexandria, Virginia, ASCD, 2000, s.2.

14 Gardner, a.g.e., Çoklu Zeka Kuramı: Zihin Çerçeveleri, s.246.

15 Linda Campbell - Bruce Campbell - Dee Dickinson, Teaching and Learning Through Multiple Intelligences, Massachusetts, Allyn \& Bacon, 1999, s. xvi.

16 İflazoğlu, a.g.e., s.24.

17 Saban, a.g.e., Çoklu Zeka Kuramı ve Türk Eğitim Sistemine Yansıması, s.17. 
Doğa zekası: Bu zeka; türleri birbirinden ayırt edebilme, tanıyabilme ve sınıflandırabilme, doğal dünyaya ilişkin bilgileri kavrayabilme kabiliyetlerini kapsar ${ }^{18}$.

Öğrenciye yardımcı olmanın yolları aranırken zayıf yönler kadar güçlü yönlere de önem verilmelidir. Etkili öğrenmenin gerçekleşebilmesi için zayıf ve güçlü yönler birlikte düşünülmelidir. Öğrencilerin güçlü yönlerini bilmelerini sağlamak, öz saygının geliştirilmesi için de önem taşır ${ }^{19}$. Öğrencilerin güçlü yönlerinin belirlenip, zayıf yönlerinin geliştirilebilmesi için baskın çoklu zeka alanlarının belirlenmesi de önemlidir.

Mimarlık ortamı çok çeşitli becerilere sahip bireyler gerektirmekte olup, çoklu zeka kuramını dikkate alan eğitim yaklaşımları ise bireylerde bulunan bütün zeka alanlarını bulmayı ve geliştirmeyi hedeflemektedir. Bu nedenle çoklu zeka kuramı mimarlık eğitimi alanında kullanılabilir.

Çoklu zeka ile ilgili yapılan literatür taraması sonucunda aşağıdaki bilgilere ulaşılmıştır.

Karabay vd. ${ }^{20}$ "Çoklu Zeka Kuramı Temelli Çalışmaların Değerlendirilmesi: Türkiye Örneği” adlı makale çalışmalarında, Yüksek Öğretim Kurumu veri tabanına kayıtl1, 1998-2010 yılları arasında yayınlanan 228 yüksek lisans ve doktora tez çalışmasından 176'sını değerlendirmiştir. Çalışmanın sonuçlarına göre, ÇZK ile ilgili yapılan tezlerin tamamı eğitim alanında ve büyük çoğunluğu ilköğretim düzeyinde yapılmıştır. Ayrıca bu çalışmaların 2006 yılından itibaren artış gösterdiği ortaya çıkmıştır.

1998-2019 yılları arasında YÖK veri tabanına kayıtlı tezler taranmış, Çoklu Zeka Alanları ile ilgili Mimarlık Anabilim dalında yapılan tez bulunmadığı görülmüştür.

Sağıroğlu'nun"21, "Mimari Tasarım Eğitiminde Çoklu Zeka Kuramından, Lefebre'nin Üçlü Mekan Diyalektiğine Uzanan Bir Öğrenme Deneyimi: Mekan Oyunları" adlı makale çalışmasında Mekan Oyunları, mantıksal -matematiksel zeka tabanına

18 Ilgın Başaran, "Etkili Öğrenme ve Çoklu Zeka Kuramı: Bir İnceleme”, Ege Eğitim Dergisi, 5, 2004, s.12.

19 Faruk Mendi - İhsan Toktaş - Ömer Karabıyı, "Tasarı Geometride Görünürlük Prensiplerinin Bilgisayar Destekli Öğretimi”, Makine Teknolojileri Elektronik Dergisi, sayı 3, 2004, s.566.

20 Ayşegül Karabay - Dilek Işık - Raziye Günay Bilaloğlu - Bilge Kuşdemir Kayıran, "Çoklu Zeka Kuramı Temelli Çalışmaların Değerlendirilmesi: Türkiye Örneği”, Ç. Ü. Sosyal Bilimler Enstitüsü Dergisi, cilt 20, sayı 2, 2011, s.21-32.

21 Pınar Meliha Sağıroğlu, "Mimari Tasarım Eğitiminde Çoklu Zeka Kuramından, Lefebre'nin Üçlü Mekan Diyalektiğine Uzanan Bir Öğrenme Deneyimi: Mekan Oyunları”, Megaron, YTÜ Mim. Fak. E-Dergisi, cilt 12, say1 1, 2017, s.78-86. 
dayalı "Orta Öğretim" aşamasından sonra uzamsal zeka kullanımına geçişte kolaylık sağlayabilecek bir zihin pratiği olarak tanımlanmıştır. Mekan Oyunları mekanın sahip olduğu tüm fiziki ve üç boyutlu niteliklerin farkına varılmasını amaçlayarak, oyunu oynayan mimarlık öğrencilerinin oynamayanlardan farklı olarak mekan tasarımına plan çizimi yerine, perspektif ifade ile başlamalarını sağlamıştır.

D'Souza ${ }^{22}$ makale çalışmasında, stüdyo ortamında Harward Gardner'ın çoklu zeka kuramını kullanan bir mimari tasarım yaklaşımı önermektedir. 36 mimarlık öğrencisinin çoklu zeka alanlarını ölçmek için, Shearer (1996) tarafından geliştirilen MIDAS (Multiple Intelligence Development Assessment Scale) anketini uygulamıştır. En yüksek puanlar uzamsal zeka ve içsel zekadadır. En düşük puanlar müziksel ve kinestetik zekadadır. Diğer zeka alanları orta derecede puanlanmıştır. Tasarım zekasının bir dizi değişkenle sınırlı olamayacağını ve konuya daha çok, arzu edilen sonuçlar almak için uyarlanabilen çoklu zekaları içeren esnek bir çerçeveden bakılması gerektiğini belirtmektedir. Bunun ise mimari tasarım problemlerinin çeşitli yollardan ve alternatif bakış açılarından çözülebileceğini gösterdiği sonucuna ulaşmıştır.

Çoklu zeka üzerine yapılan çalışmalar incelendiğinde, mimarlık öğrencilerinin Çoklu Zeka Alanlarını inceleyen Ulusal düzeyde bir çalışma olmadığı görülmüştür. Bu nedenle mevcut çalışma ile Mimarlık bölümlerinde öğrenim gören öğrencilerin çoklu zeka alanlarına ait ortalama puanlarının belirlenip, zeka puanları arasındaki ilişkinin tespit edilmesi ve çoklu zeka alanlarının cinsiyet değişkenine göre incelenmesi amaçlanmıştır. Böylece elde edilen bilgiden mimarlık eğitimi sürecinde faydalanılabilecektir.

\section{Yöntem}

\section{Araştırmanın Deseni}

Araştırmada çalışma deseni niceldir ve mimarlık öğrencilerinin çoklu zeka alanlarına ait veriler toplanmıştır. Çoklu zeka alanlarına ait verilerin yanında, çoklu zeka alanlarının cinsiyet değişkenine göre karşılaştırma sonuçları da incelenmiştir.

\section{Çalıșma Grubu}

Çalışma, 2017-2018 öğretim yılında Fatih Sultan Mehmet Vakıf Üniversitesi (FSMVÜ) Mimarlık bölümünde Mimari Anlatım Dili, Yıldız Teknik Üniversitesi(YTÜ) Mimarlık bölümünde Mimari Anlatım Teknikleri ve Mimar Sinan

22 Newton D'Souza, "Design Intelligences: A Case For Multiple Intelligences In Architectural Design”, Archnet-International of Architectural Design, volume, issue 2, July 2007, s.15-34. 
Güzel Sanatlar Üniversitesi (MSGSÜ) Mimarlık bölümünde Mimari Teknik Resim derslerini alan toplam 279 öğrenci ile yürütülmüştür. Bu öğrencilerden 46's1 FSMVÜ Mimarlık Bölümü, 86's1 YTÜ Mimarlık Bölümü ve 147'si MSGSÜ Mimarlık Bölümünde lisans eğitimi görmektedir.

\section{Veri Toplama Aracı}

Araştırmanın verileri, Branton Shearer ${ }^{23}$ ' 1 n geliştirdiği ve Ayten İflazoğlu Saban vd. ${ }^{24}$ 'nin Türkçe Uyarlamasının Geçerlik ve Güvenilirlik çalışmasını yaptıkları Çoklu Zeka Alanları Gelişimsel Değerlendirme Ölçeği (MIDAS) yardımıyla toplanmıştır. Çoklu Zeka Kuramını geliştiren Howard Gardner da, Branton Shearer'ın "The MIDAS: A Professional Manual” adlı çalışmasının önsözünde, MIDAS (Çoklu Zeka Alanları Gelişimsel Değerlendirme Ölçeği)'ın değerlendirme yaklaşımını desteklediğini belirtmektedir.

Çalışmada kullanılan Çoklu Zeka Ölçeği 93 sorudan oluşmaktadır. Bu sorular, öğrencilerin ilgili alandaki yetenek ve becerilerini ölçmeye yönelik olarak A'dan F'ye altı seçenekli ve Likert tipi sorulardır. "Likert-tipi sorular araştırılan konu hakkında tutum veya görüş içeren bir ifade ve bu ifadeye katılım düzeyini belirten seçenekler içerir. Bu seçenekler 'en yüksekten en düşüğe' veya 'en iyiden en kötüye' doğru dereceli bir şekilde sıralanır"25. Ölçekte müziksel zekaya yönelik 13, bedensel zekaya yönelik 10, matematiksel zekaya yönelik 14, uzamsal zekaya yönelik 10, dilsel zekaya yönelik 13, sosyal zekaya yönelik 14, içsel zekaya yönelik 7 ve doğa zekasına yönelik 12 soru bulunmaktadır.

\section{Verilerin Toplanması ve Analizi}

Ölçekler FSMVÜ Mimarlık Bölümünde Mimari Anlatım Dili dersini alan öğrencilere 28.11.2017 tarihinde dağıtılıp, 1 hafta süre verilerek 1 hafta sonra toplanmıştır. YTÜ Mimarlık Bölümünde Mimari Anlatım Teknikleri dersini alan öğrencilere 11.12.2017 tarihinde dağıtılıp, 1 hafta süre verilerek 1 hafta sonra toplanmıştır. MSGSÜ Mimarlık Bölümünde ise Mimari Teknik Resim dersini alan öğrencilere 29.11.2017 ve 30.11.2017 tarihlerinde iki kısım halinde dağıtılıp ölçeğin cevaplanması süresince beklenerek, cevaplandıktan sonra aynı gün top-

23 Branton Shearer, The MIDAS: A Professional Manual, 1996.

24 Ayten İflazoğlu Saban - Branton Shearer - Bilge Kuşdemir Kayıran - Dilek Işı, "The Validity and Reliability Study Of Turkish Version Of The Multiple Intelligences Developmental Assessment Scales", International Journal Of Human Sciences, volume 9, issue 2, 2012, s.651-666.

25 İbrahim Turan - Ümit Şimşek - Hasan Aslan, "Eğitim Araştırmalarında Likert Ölçeği ve Likert-Tipi Soruların Kullanımı ve Analizi”, Sakarya Üniversitesi Ĕ̌itim Fakültesi Dergisi, sayı 30, 2015, s.188. 
lanmıştır. Toplanan toplam 279 anketten 265'i değerlendirmeye alınmıştır. Bunların üniversitelere göre dağılımı ise şöyledir; FSMVÜ'den toplanan 46 anketten 46's1, MSGSÜ'den toplanan 147 anketten 139'u ve YTÜ'den toplanan 86 anketten 80 'i değerlendirmeye alınmıştır.Ölçeklerden elde edilen veriler öncelikle bilgisayar ortamında Excel programına aktarılmıştır. Ardından SPSS (Statistical Package For Social Sciences) paket programına yüklenerek değerlendirilmiştir.

Ölçeklerin değerlendirilmesinde, "bilmiyorum", "bilmiyorum, hatırlamıyorum" gibi seçenekler boş bırakılmış varsayılarak değerlendirmeye alınmamakta ${ }^{26}$, puana katkıda bulunmayan kayıp değerler olarak kabul edilmektedir $^{27}$. Diğer seçeneklere verilen puanlar 0 ile 4 arasında değişen Likert tipi beşli derecelendirme ölçeğine dönüştürülmektedir ${ }^{28}$. Her alt ölçek için katılımcının aldığı puanlar toplanarak, alabileceği en yüksek puan değerine bölünerek hesaplamalar yapilabilmektedir ${ }^{29}$.

“Örnek: Çocukken müziği ya da müzik derslerini sever miydiniz?
A) Hayır (0)
B) Çok nadir (1)
C) Bazen (2)
D) Hemen hemen her zaman (3)
E) Her zaman (4) F) Bilmiyorum, hatırlamıyorum (boş)"30

\section{Bulgular}

Üç üniversiteden toplanan anketlerden değerlendirmeye alınan toplam 265 ankete göre katılımc1ların 46's1 FSMVÜ, 80'i YTÜ ve 139'u MSGSÜ öğrencisidir. 265 anketin \%17'si FSMVÜ, \%30’u YTÜ ve \%53'ü MSGSÜ öğrencilerine uygulanmıştır. Değerlendirmeye alınan anketlerden $145^{\prime} \mathrm{i}$ kız, 120 'si ise erkek öğrencilere uygulanmıştır. 265 öğrencinin \%55'i kız, \%45'i ise erkektir.

Çoklu Zeka Alanları Belirleme Ölçeğinden elde edilen bulgular dört başlık altında incelenmiştir. Öncelikle soruların Cronbach-Alfa güvenirlik analizi yapı1mıştır. Ardından, ölçek tüm öğrenciler düzeyinde ve üniversitelere göre değerlendirilmiş ve öğrencilerin çoklu zeka alanlarına ait zeka puanları arasındaki ilişki incelenmiştir. Son olarak cinsiyet ve çoklu zeka alanları arasındaki ilişki hem tüm öğrenciler düzeyinde hem de üniversitelere göre incelenmiştir.

26 İflazoğlu Saban - Shearer - Kayıran - Işık, a.g.e., s.666.

27 Erkan T. Demirel - Muhammet Düşükcan - Mehmet Ölmez, "Çoklu Zeka Alanlarının Girişimcilik Davranışına Etkisi”, Organizasyon ve Yönetim Bilimleri Dergisi, cilt 3, sayı 2, 2011, s.101.

28 İflazoğlu Saban - Shearer - Kayıran ve Işık, a.g.e., s.666.

29 Demirel - Düşükcan - Ölmez, a.g.e., s.101.

30 İflazoğlu Saban - Shearer - Kayıran - Işık, a.g.e., s.666. 


\section{Çoklu Zeka Alanları Belirleme Ölçeğindeki Soruların Cronbach-Alfa Güvenirlik Analizi}

Cronbach alfa katsayısı, maddelerin iç tutarlılığının bir ölçüsü olarak ifade edilir. Ölçekte bulunan maddelerin homojen yapısını açıklamak veya sorgulamak amacıyla kullanılır. Cronbach alfa katsayısı yüksek ise o ölçekteki maddelerin birbirleriyle tutarlı ve bir o kadar da aynı özelliği ölçen maddelerden meydana geldiği söylenebilir. Likert tipli ölçeklerde sıklıkla kullanılan Cronbach alfa, aşağdaki gibi ifade edilir; ${ }^{31}$

$0<\mathrm{R}_{2}<0.40$ ise güvenilir değil

$0.40<\mathrm{R}_{2}<0.60$ ise düşük güvenilirlikte

$0.60<\mathrm{R}_{2}<0.80$ ise oldukça güvenilir

$0.80<\mathrm{R}_{2}<1.00$ ise yüksek güvenilirlikte. ${ }^{32}$

Tablo 1'de çoklu zeka alanlarıyla ilgili Cronbach-Alfa Güvenirlik Analizi sonuçları verilmiştir.

Tablo 1. Cronbach-Alfa Güvenirlik Analizi Sonuçları

\begin{tabular}{|l|l|l|}
\hline Zeka Alanı & Cronbach's Alpha & Madde sayısı \\
\hline Müziksel Zeka & 0.850 & 13 \\
\hline Bedensel Zeka & 0.757 & 10 \\
\hline Matematiksel Zeka & 0.805 & 14 \\
\hline Uzamsal Zeka & 0.828 & 10 \\
\hline Dilsel Zeka & 0.843 & 13 \\
\hline Sosyal Zeka & 0.811 & 14 \\
\hline İsel Zeka & 0.815 & 7 \\
\hline Doğacı Zeka & 0.849 & 12 \\
\hline
\end{tabular}

Tablo 1'deki sonuçlar değerlendirildiğinde; bedensel zeka alanına ait alfa değerinin oldukça güvenilir, diğer zeka alanlarına ait alfa değerlerinin ise yüksek güvenilirlikte olduğu ortaya çıkmıştır. Böylelikle ölçekte yer alan tüm zeka alanlarının kendi içinde tutarlı olduğu sonucu çıarılmıştır.

31 Doğan Yıldız - Ece Uzunsakal, “Alan Araştırmalarında Güvenilirlik Testlerinin Karşılaştırılması ve Tarımsal Veriler Üzerine Bir Uygulama”, Uygulamalı Sosyal Bilimler Dergisi, 2018, say1 1, s.19.

32 Y1ldiz - Uzunsakal, a.g.e., s.19. 


\section{Çoklu Zeka Alanları Belirleme Ölçeğinin Tüm Öğrenciler Düzeyinde Değerlendirme Sonuçları}

Mimarlık öğrencilerinin çoklu zeka alanlarına ait puanlarının ortalaması Tablo 2'de sunulmuştur.

Tablo 2. Çoklu zeka alanları ortalama puanları

\begin{tabular}{|l|c|}
\hline Zeka Alanı & Ortalama Zeka Puanı \\
\hline Sosyal Zeka & 0.620 \\
\hline İçsel Zeka & 0.612 \\
\hline Matematiksel Zeka & 0.606 \\
\hline Müziksel Zeka & 0.573 \\
\hline Uzamsal Zeka & 0.486 \\
\hline Bedensel Zeka & 0.461 \\
\hline Dilsel Zeka & 0.458 \\
\hline Doğacı Zeka & 0.402 \\
\hline
\end{tabular}

Tablo 2'den mimarlık öğrencilerinin en yüksek puanlı zeka alanının sosyal zeka, en düşük puanlı zeka alanının ise doğacı zeka olduğu ortaya çıkmıştır. Şekil 1'de Tablo 2'nin grafik olarak ifadesi sunulmuştur.

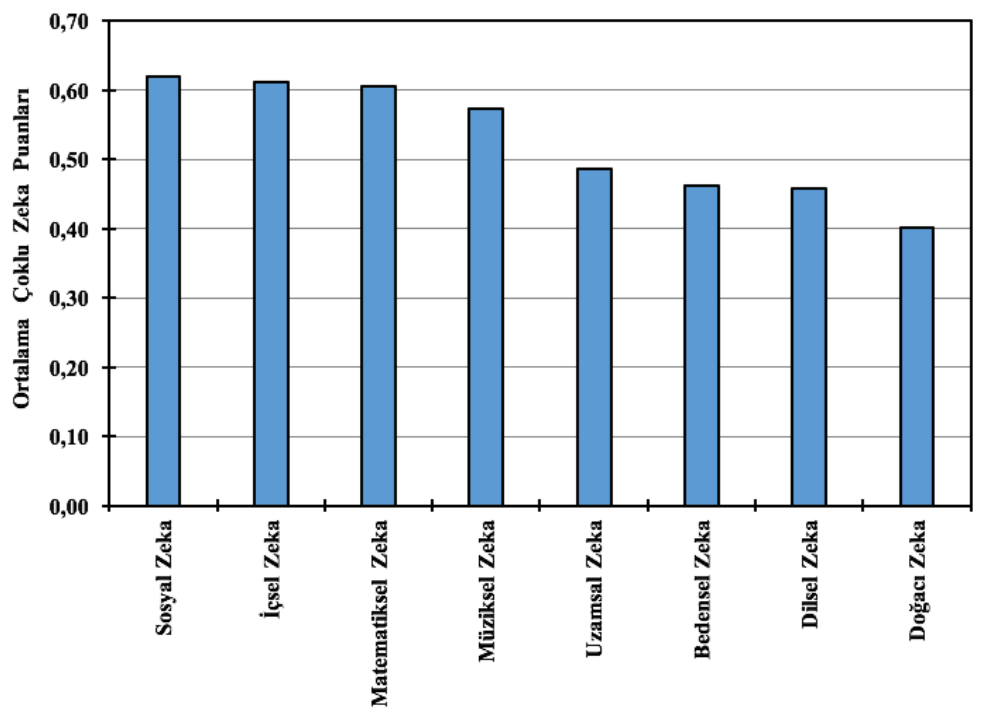

Şekil 1. Çoklu zeka alanları ortalama puanları 
Mimarlık öğrencilerinin çoklu zeka alanlarına ait zeka puanları arasındaki ilişkinin belirlenebilmesi için, üç üniversitedeki öğrencilerin tümünün zeka puanları arasında Pearson Korelasyon Analizi yapılmıştır. Mimarlık öğrencilerinin zeka puanları arasında yapılan Pearson Korelasyon Analizi sonuçları Tablo 3'te sunulmuştur.

Tablo 3. Mimarlık öğrencilerinin zeka puanları arasında yapılan Pearson Korelasyon Analizi sonuçları

\section{Correlations}

\begin{tabular}{|c|c|c|c|c|c|c|c|c|c|c|}
\hline & & $\mathbf{N}$ & \begin{tabular}{|l|} 
Müziksel \\
Zeka
\end{tabular} & $\begin{array}{l}\text { Bedensel } \\
\text { Zeka }\end{array}$ & $\begin{array}{l}\text { Matematiksel } \\
\text { Zeka }\end{array}$ & $\begin{array}{l}\text { Uzamsal } \\
\text { Zeka }\end{array}$ & $\begin{array}{l}\text { Dilsel } \\
\text { Zeka }\end{array}$ & $\begin{array}{l}\text { Sosyal } \\
\text { Zeka }\end{array}$ & $\begin{array}{l}\text { İçsel } \\
\text { Zeka }\end{array}$ & $\begin{array}{l}\text { Doğacı } \\
\text { Zeka }\end{array}$ \\
\hline \multirow[t]{2}{*}{$\begin{array}{l}\text { Müziksel } \\
\text { Zeka }\end{array}$} & $\begin{array}{l}\text { Pearson } \\
\text { Correlation }\end{array}$ & 265 & 1 & $0.12^{*}$ & $0.17^{*}$ & $0.26^{*}$ & $0.35^{*}$ & $0.25^{*}$ & $0.27^{*}$ & $0.21^{*}$ \\
\hline & Sig. (2-tailed) & & & 0.04 & 0.01 & 0.00 & 0.00 & 0.00 & 0.00 & 0.00 \\
\hline \multirow[t]{2}{*}{$\begin{array}{l}\text { Bedensel } \\
\text { Zeka }\end{array}$} & $\begin{array}{l}\text { Pearson } \\
\text { Correlation }\end{array}$ & 265 & & 1 & $0.25^{*}$ & $0.37^{*}$ & $0.31^{*}$ & $0.34^{*}$ & $0.35^{*}$ & $0.28^{*}$ \\
\hline & Sig. (2-tailed) & & & & 0.00 & 0.00 & 0.00 & 0.00 & 0.00 & 0.00 \\
\hline \multirow[t]{2}{*}{$\begin{array}{l}\text { Matematiksel } \\
\text { Zeka }\end{array}$} & $\begin{array}{l}\text { Pearson } \\
\text { Correlation }\end{array}$ & 265 & & & 1 & $0.46^{*}$ & $0.40^{*}$ & $0.41^{*}$ & $0.40^{*}$ & $0.24^{*}$ \\
\hline & Sig. (2-tailed) & & & & & 0.00 & 0.00 & 0.00 & 0.00 & 0.00 \\
\hline \multirow[t]{2}{*}{$\begin{array}{l}\text { Uzamsal } \\
\text { Zeka }\end{array}$} & $\begin{array}{l}\text { Pearson } \\
\text { Correlation }\end{array}$ & 265 & & & & 1 & $0.37^{*}$ & $0.44^{*}$ & $0.53^{*}$ & $0.45^{*}$ \\
\hline & Sig. (2-tailed) & & & & & & 0.00 & 0.00 & 0.00 & 0.00 \\
\hline \multirow[t]{2}{*}{ Dilsel Zeka } & $\begin{array}{l}\text { Pearson } \\
\text { Correlation }\end{array}$ & 265 & & & & & 1 & $0.49^{*}$ & $0.45^{*}$ & $0.33^{*}$ \\
\hline & Sig. (2-tailed) & & & & & & & 0.00 & 0.00 & 0.00 \\
\hline \multirow[t]{2}{*}{ Sosyal Zeka } & $\begin{array}{l}\text { Pearson } \\
\text { Correlation }\end{array}$ & 265 & & & & & & 1 & $0.58^{*}$ & $0.25^{*}$ \\
\hline & Sig. (2-tailed) & & & & & & & & 0.00 & 0.00 \\
\hline \multirow[t]{2}{*}{ İçsel Zeka } & $\begin{array}{l}\text { Pearson } \\
\text { Correlation }\end{array}$ & 265 & & & & & & & 1 & $0.35^{*}$ \\
\hline & Sig. (2-tailed) & & & & & & & & & 0.00 \\
\hline \multirow[t]{2}{*}{ Doğacı Zeka } & $\begin{array}{l}\text { Pearson } \\
\text { Correlation }\end{array}$ & 265 & & & & & & & & 1 \\
\hline & Sig. (2-tailed) & & & & & & & & & \\
\hline
\end{tabular}

*. Correlation is significant at the 0.05 level (2-tailed). 
Üç üniversitedeki öğrencilerin tümünün zeka puanları arasında yapılan Pearson Korelasyon Analizi sonuçlarına göre;

- Müziksel zeka puanları ile diğer zeka puanları arasındaki ilişki incelendiğinde, en yüksek korelasyon katsayısı dilsel zekada olduğundan $(\mathrm{r}=0.35)$, müziksel zeka ile en fazla dilsel zeka arasında anlamlı bir ilişki olduğu söylenebilir $(\mathrm{p}<0.05)$.

- Bedensel zeka puanları ile diğer zeka puanları arasındaki ilişki incelendiğinde, en yüksek korelasyon katsayısı uzamsal zekada olduğundan $(\mathrm{r}=0.37)$, bedensel zeka ile en fazla uzamsal zeka arasinda anlamlı bir ilişki olduğu söylenebilir $(\mathrm{p}<0.05)$.

- Matematiksel zeka puanları ile diğer zeka puanları arasındaki ilişki incelendiğinde, en yüksek korelasyon katsayısı uzamsal zekada olduğundan $(\mathrm{r}=0.46)$, matematiksel zeka ile en fazla uzamsal zeka arasında anlamlı bir ilişki olduğu söylenebilir $(\mathrm{p}<0.05)$.

- Uzamsal zeka puanları ile diğer zeka puanları arasındaki ilişki incelendiğinde, en yüksek korelasyon katsayısı içsel zekada olduğundan ( $\mathrm{r}=0.53)$, uzamsal zeka ile en fazla içsel zeka arasında anlamlı bir ilişki olduğu söylenebilir $(\mathrm{p}<0.05)$.

- Dilsel zeka puanları ile diğer zeka puanları arasındaki ilişki incelendiğinde, en yüksek korelasyon katsayısı sosyal zekada olduğundan ( $\mathrm{r}=0.49)$, dilsel zeka ile en fazla sosyal zeka arasında anlamlı bir ilişki olduğu söylenebilir $(\mathrm{p}<0.05)$.

- Sosyal zeka puanları ile diğer zeka puanları arasındaki ilişki incelendiğinde, en yüksek korelasyon katsayısı içsel zekada olduğundan ( $\mathrm{r}=0.58)$, sosyal zeka ile en fazla içsel zeka arasında anlamlı bir ilişki olduğu söylenebilir $(\mathrm{p}<0.05)$.

- İçsel zeka puanları ile diğer zeka puanları arasındaki ilişki incelendiğinde, en yüksek korelasyon katsayısı sosyal zekada olduğundan ( $r=0.58)$, içsel zeka ile en fazla sosyal zeka arasında anlamlı bir ilişki olduğu söylenebilir $(\mathrm{p}<0.05)$.

- Doğacı zeka puanları ile diğer zeka puanları arasındaki ilişki incelendiğinde, en yüksek korelasyon katsayısı uzamsal zekada olduğundan ( $\mathrm{r}=0.45)$, doğacı zeka ile en fazla uzamsal zeka arasında anlamlı bir ilişki olduğu söylenebilir $(\mathrm{p}<0.05)$.

\section{Çoklu Zeka Alanları Belirleme Ölçeğinin Üniversitelere Göre Değerlendirme Sonuçları}

Mimarlık öğrencilerinin üniversitelerine göre çoklu zeka alanlarına ait puanlarının ortalaması Tablo 4'te verilmiştir. 
Tablo 4. Üniversitelere Göre Çoklu Zeka Alanlarının Ortalama Puanları

\begin{tabular}{|l|c|c|c|}
\hline Zeka Alanı & $\begin{array}{c}\text { FSMVÜ } \\
\text { Ortalama Zeka } \\
\text { Puanı }\end{array}$ & $\begin{array}{c}\text { YTÜ } \\
\text { Ortalama Zeka } \\
\text { Puanı }\end{array}$ & $\begin{array}{c}\text { MSGSÜ } \\
\text { Ortalama Zeka } \\
\text { Puanı }\end{array}$ \\
\hline Sosyal Zeka & 0.637 & 0.637 & 0.605 \\
\hline İçsel Zeka & 0.631 & 0.667 & 0.573 \\
\hline $\begin{array}{l}\text { Matematiksel } \\
\text { Zeka }\end{array}$ & 0.582 & 0.647 & 0.590 \\
\hline Müziksel Zeka & 0.580 & 0.544 & 0.586 \\
\hline Uzamsal Zeka & 0.493 & 0.540 & 0.452 \\
\hline Bedensel Zeka & 0.502 & 0.470 & 0.443 \\
\hline Dilsel Zeka & 0.503 & 0.444 & 0.451 \\
\hline Doğacı Zeka & 0.420 & 0.410 & 0.391 \\
\hline
\end{tabular}

Tablo 4'te çoklu zeka alanlarına ait ortalama zeka puanları üniversiteler düzeyinde incelendiğinde, MSGSÜ öğrencilerinin müziksel zeka alanında diğer üniversitelerdeki öğrencilerden daha yüksek puan aldığı belirlenmiştir. FSMVÜ öğrencileri bedensel, dilsel ve doğacı zeka alanlarında daha yüksek puan almıştır. YTÜ öğrencilerinin ise içsel, matematiksel ve uzamsal ortalama zeka puanları daha yüksek çıkmıştır. Şekil 2'de Tablo 4'ün grafik olarak ifadesi sunulmuştur.

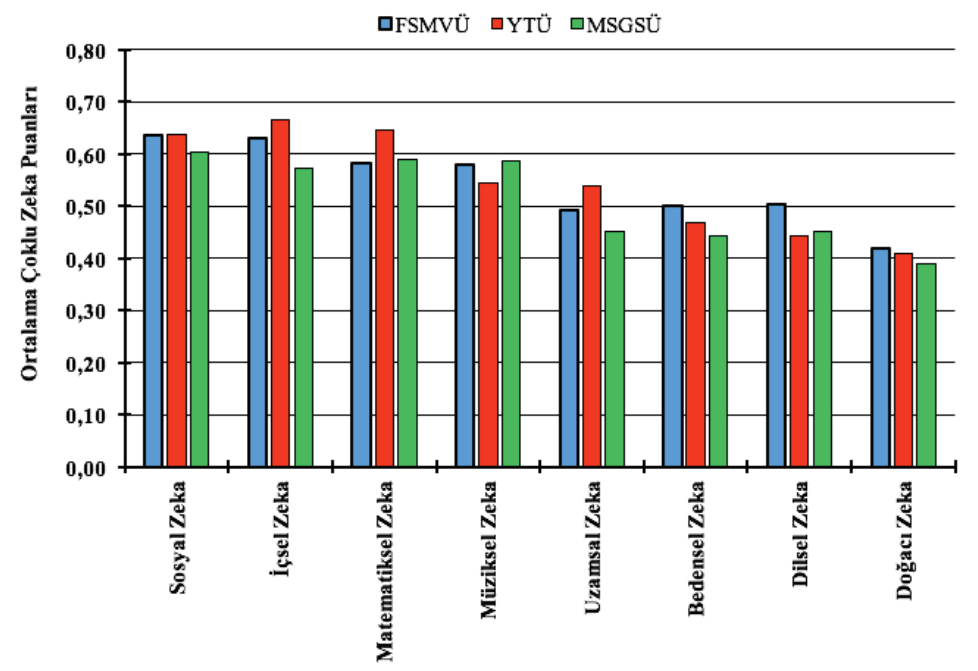

Şekil 2. Üniversitelere göre çoklu zeka alanlarının ortalama puanları 
Üniversitelere göre öğrencilerin çoklu zeka alanlarına ait puanları arasındaki ilişkiyi belirlemek amacıyla, ayrı ayrı üç üniversite için öğrencilerin zeka puanları arasında Pearson Korelasyon Analizi yapılmıştır. FSMVÜ öğrencilerinin zeka puanları arasında yapılan Pearson Korelasyon Analizi sonuçları Tablo 5'te sunulmuştur.

Tablo 5. FSMVÜ öğrencilerinin zeka puanları arasında yapılan

Pearson Korelasyon Analizi sonuçları

\section{Correlations}

\begin{tabular}{|c|c|c|c|c|c|c|c|c|c|c|}
\hline & & $\mathbf{N}$ & $\begin{array}{c}\text { Müziksel } \\
\text { Zeka }\end{array}$ & $\begin{array}{c}\text { Bedensel } \\
\text { Zeka }\end{array}$ & $\begin{array}{c}\text { Matematiksel } \\
\text { Zeka }\end{array}$ & $\begin{array}{c}\text { Uzamsal } \\
\text { Zeka }\end{array}$ & $\begin{array}{r}\text { Dilsel } \\
\text { Zeka }\end{array}$ & $\begin{array}{c}\text { Sosyal } \\
\text { Zeka }\end{array}$ & $\begin{array}{l}\text { İçsel } \\
\text { Zeka }\end{array}$ & $\begin{array}{c}\text { Doğacı } \\
\text { Zeka }\end{array}$ \\
\hline \multirow[t]{2}{*}{$\begin{array}{l}\text { Müziksel } \\
\text { Zeka }\end{array}$} & $\begin{array}{l}\text { Pearson } \\
\text { Correlation }\end{array}$ & 46 & 1 & $0,3^{*}$ & 0,18 & 0,25 & $0,36^{*}$ & 0,22 & $0,49^{*}$ & $\mathbf{0 , 4 0}$ \\
\hline & Sig. (2-tailed) & & & 0,03 & 0,23 & 0,09 & 0,01 & 0,15 & 0,00 & 0,01 \\
\hline \multirow[t]{2}{*}{$\begin{array}{l}\text { Bedensel } \\
\text { Zeka }\end{array}$} & $\begin{array}{l}\text { Pearson } \\
\text { Correlation }\end{array}$ & 46 & & 1 & $0,48^{*}$ & $0,45^{*}$ & 0,26 & $\mathbf{0 , 5 1} 1^{*}$ & $0,44^{*}$ & $0,35^{*}$ \\
\hline & Sig. (2-tailed) & & & & 0,00 & 0,00 & 0,08 & 0,00 & 0,00 & 0,02 \\
\hline \multirow[t]{2}{*}{$\begin{array}{l}\text { Matematiksel } \\
\text { Zeka }\end{array}$} & $\begin{array}{l}\text { Pearson } \\
\text { Correlation }\end{array}$ & 46 & & & 1 & $0,37^{*}$ & $0,31^{*}$ & $\mathbf{0 , 3 1}{ }^{*}$ & $0,38^{*}$ & $0,42^{*}$ \\
\hline & Sig. (2-tailed) & & & & & 0,01 & 0,04 & 0,04 & 0,01 & 0,00 \\
\hline \multirow[t]{2}{*}{$\begin{array}{l}\text { Uzamsal } \\
\text { Zeka }\end{array}$} & $\begin{array}{l}\text { Pearson } \\
\text { Correlation }\end{array}$ & 46 & & & & 1 & 0,21 & $0,44^{*}$ & $0,53^{*}$ & $0,57^{*}$ \\
\hline & Sig. (2-tailed) & & & & & & 0,16 & 0,00 & 0,00 & 0,00 \\
\hline \multirow[t]{2}{*}{ Dilsel Zeka } & $\begin{array}{l}\text { Pearson } \\
\text { Correlation }\end{array}$ & 46 & & & & & 1 & $0, \mathbf{4 3}^{*}$ & $0,52^{*}$ & $0,37^{*}$ \\
\hline & Sig. (2-tailed) & & & & & & & 0,00 & 0,00 & 0,01 \\
\hline \multirow[t]{2}{*}{ Sosyal Zeka } & $\begin{array}{l}\text { Pearson } \\
\text { Correlation }\end{array}$ & 46 & & & & & & 1 & $0,53^{*}$ & $0,34^{*}$ \\
\hline & Sig. (2-tailed) & & & & & & & & 0,00 & 0,02 \\
\hline \multirow[t]{2}{*}{ İçsel Zeka } & $\begin{array}{l}\text { Pearson } \\
\text { Correlation }\end{array}$ & 46 & & & & & & & 1 & $0,59^{*}$ \\
\hline & Sig. (2-tailed) & & & & & & & & & 0,00 \\
\hline \multirow[t]{2}{*}{ Doğacı Zeka } & $\begin{array}{l}\text { Pearson } \\
\text { Correlation }\end{array}$ & 46 & & & & & & & & 1 \\
\hline & Sig. (2-tailed) & & & & & & & & & \\
\hline
\end{tabular}

*. Correlation is significant at the 0.05 level (2-tailed). 
FSMVÜ öğrencilerinin zeka puanları arasında yapılan Pearson Korelasyon Analizi sonuçlarına göre;

- Müziksel zeka puanları ile diğer zeka puanları arasındaki ilişki incelendiğinde, en yüksek korelasyon katsayısı içsel zekada olduğundan $(\mathrm{r}=0.49)$, müziksel zeka ile en fazla içsel zeka arasında anlamlı bir ilişki olduğu söylenebilir $(\mathrm{p}<0.05)$.

- Bedensel zeka puanları ile diğer zeka puanları arasındaki ilişki incelendiğinde, en yüksek korelasyon katsayısı sosyal zekada olduğundan $(\mathrm{r}=0.51)$, bedensel zeka ile en fazla sosyal zeka arasında anlamlı bir ilişki olduğu söylenebilir $(\mathrm{p}<0.05)$.

- Matematiksel zeka puanları ile diğer zeka puanları arasındaki ilişki incelendiğinde, en yüksek korelasyon katsayısı bedensel zekada olduğundan $(\mathrm{r}=0.48)$, matematiksel zeka ile en fazla bedensel zeka arasinda anlamlı bir ilişki olduğu söylenebilir $(\mathrm{p}<0.05)$.

- Uzamsal zeka puanları ile diğer zeka puanları arasındaki ilişki incelendiğinde, en yüksek korelasyon katsayısı doğac1 zekada olduğundan $(\mathrm{r}=0.57)$, uzamsal zeka ile en fazla doğacı zeka arasında anlamlı bir ilişki olduğu söylenebilir $(\mathrm{p}<0.05)$.

- Dilsel zeka puanları ile diğer zeka puanları arasındaki ilişki incelendiğinde, en yüksek korelasyon katsayısı içsel zekada olduğundan $(\mathrm{r}=0.52)$, dilsel zeka ile en fazla içsel zeka arasında anlamlı bir ilişki olduğu söylenebilir $(\mathrm{p}<0.05)$.

- Sosyal zeka puanları ile diğer zeka puanları arasındaki ilişki incelendiğinde, en yüksek korelasyon katsayısı içsel zekada olduğundan ( $\mathrm{r}=0.53)$, sosyal zeka ile en fazla içsel zeka arasında anlamlı bir ilişki olduğu söylenebilir $(\mathrm{p}<0.05)$.

- İçsel zeka puanları ile diğer zeka puanları arasındaki ilişki incelendiğinde, en yüksek korelasyon katsayısı doğacı zekada olduğundan ( $\mathrm{r}=0.59)$, içsel zeka ile en fazla doğacı zeka arasında anlamlı bir ilişki olduğu söylenebilir $(\mathrm{p}<0.05)$.

- Doğacı zeka puanları ile diğer zeka puanları arasındaki ilişki incelendiğinde, en yüksek korelasyon katsayısı içsel zekada olduğundan ( $\mathrm{r}=0.59)$, doğacı zeka ile en fazla içsel zeka arasında anlamlı bir ilişki olduğu söylenebilir $(\mathrm{p}<0.05)$. 
YTÜ öğrencilerinin zeka puanları arasında yapılan Pearson Korelasyon Analizi sonuçları Tablo 6'da sunulmuştur.

Tablo 6. YTÜ ögrencilerinin zeka puanları arasında yapılan

Pearson Korelasyon Analizi sonuçları

Correlations

\begin{tabular}{|c|c|c|c|c|c|c|c|c|c|c|}
\hline & & $\mathbf{N}$ & $\begin{array}{l}\text { Müziksel } \\
\text { Zeka }\end{array}$ & $\begin{array}{l}\text { Bedensel } \\
\text { Zeka }\end{array}$ & $\begin{array}{l}\text { Matematiksel } \\
\text { Zeka }\end{array}$ & $\begin{array}{l}\text { Uzamsal } \\
\text { Zeka }\end{array}$ & $\begin{array}{r}\text { Dilsel } \\
\text { Zeka }\end{array}$ & $\begin{array}{l}\text { Sosyal } \\
\text { Zeka }\end{array}$ & $\begin{array}{l}\text { İçsel } \\
\text { Zeka }\end{array}$ & $\begin{array}{l}\text { Doğacı } \\
\text { Zeka }\end{array}$ \\
\hline \multirow[t]{2}{*}{$\begin{array}{l}\text { Müziksel } \\
\text { Zeka }\end{array}$} & $\begin{array}{l}\text { Pearson } \\
\text { Correlation }\end{array}$ & 80 & 1 & $-0,06$ & 0,13 & $0,28^{*}$ & $0,25^{*}$ & 0,22 & 0,20 & $0,25^{*}$ \\
\hline & Sig. (2-tailed) & & & 0,62 & 0,25 & 0,01 & 0,03 & 0,05 & 0,08 & 0,03 \\
\hline \multirow[t]{2}{*}{$\begin{array}{l}\text { Bedensel } \\
\text { Zeka }\end{array}$} & $\begin{array}{l}\text { Pearson } \\
\text { Correlation }\end{array}$ & 80 & & 1 & 0,17 & $0,29^{*}$ & $0,44^{*}$ & $0,36^{*}$ & $0,33^{*}$ & $0,25^{*}$ \\
\hline & Sig. (2-tailed) & & & & 0,13 & 0,01 & 0,00 & 0,00 & 0,00 & 0,03 \\
\hline \multirow[t]{2}{*}{$\begin{array}{l}\text { Matematiksel } \\
\text { Zeka }\end{array}$} & $\begin{array}{l}\text { Pearson } \\
\text { Correlation }\end{array}$ & 80 & & & 1 & $0,47^{*}$ & $0,33^{*}$ & $0,42^{*}$ & $0,29^{*}$ & $0,29^{*}$ \\
\hline & Sig. (2-tailed) & & & & & 0,00 & 0,00 & 0,00 & 0,01 & 0,01 \\
\hline \multirow[t]{2}{*}{$\begin{array}{l}\text { Uzamsal } \\
\text { Zeka }\end{array}$} & $\begin{array}{l}\text { Pearson } \\
\text { Correlation }\end{array}$ & 80 & & & & 1 & $0,43^{*}$ & $0,55^{*}$ & $0,60^{*}$ & $0,50^{*}$ \\
\hline & Sig. (2-tailed) & & & & & & 0,00 & 0,00 & 0,00 & 0,00 \\
\hline \multirow[t]{2}{*}{ Dilsel Zeka } & $\begin{array}{l}\text { Pearson } \\
\text { Correlation }\end{array}$ & 80 & & & & & 1 & $0,59^{*}$ & $0,43^{*}$ & $0,31^{*}$ \\
\hline & Sig. (2-tailed) & & & & & & & 0,00 & 0,00 & 0,01 \\
\hline \multirow[t]{2}{*}{ Sosyal Zeka } & $\begin{array}{l}\text { Pearson } \\
\text { Correlation }\end{array}$ & 80 & & & & & & 1 & $0,66^{*}$ & $0,30^{*}$ \\
\hline & Sig. (2-tailed) & & & & & & & & 0,00 & 0,01 \\
\hline \multirow[t]{2}{*}{ İçsel Zeka } & $\begin{array}{l}\text { Pearson } \\
\text { Correlation }\end{array}$ & 80 & & & & & & & 1 & $0,28^{*}$ \\
\hline & Sig. (2-tailed) & & & & & & & & & 0,01 \\
\hline \multirow[t]{2}{*}{ Doğacı Zeka } & $\begin{array}{l}\text { Pearson } \\
\text { Correlation }\end{array}$ & 80 & & & & & & & & 1 \\
\hline & Sig. (2-tailed) & & & & & & & & & \\
\hline
\end{tabular}

*. Correlation is significant at the 0.05 level (2-tailed). 
YTÜ öğrencilerinin zeka puanları arasında yapılan Pearson Korelasyon Analizi sonuçlarına göre,

- Müziksel zeka puanları ile diğer zeka puanları arasındaki ilişki incelendiğinde, en yüksek korelasyon katsayısı uzamsal zekada olduğundan $(\mathrm{r}=0.28)$, müziksel zeka ile en fazla uzamsal zeka arasında anlamlı bir ilişki olduğu söylenebilir $(\mathrm{p}<0.05)$.

- Bedensel zeka puanları ile diğer zeka puanları arasındaki ilişki incelendiğinde, en yüksek korelasyon katsayısı dilsel zekada olduğundan $(\mathrm{r}=0.44)$, bedensel zeka ile en fazla dilsel zeka arasında anlamlı bir ilişki olduğu söylenebilir $(\mathrm{p}<0.05)$.

- Matematiksel zeka puanları ile diğer zeka puanları arasındaki ilişki incelendiğinde, en yüksek korelasyon katsayısı uzamsal zekada olduğundan $(\mathrm{r}=0.47)$, matematiksel zeka ile en fazla uzamsal zeka arasinda anlamlı bir ilişki olduğu söylenebilir $(\mathrm{p}<0.05)$.

- Uzamsal zeka puanları ile diğer zeka puanları arasındaki ilişki incelendiğinde, en yüksek korelasyon katsayısı içsel zekada olduğundan $(\mathrm{r}=0.60)$, uzamsal zeka ile en fazla içsel zeka arasında anlamlı bir ilişki olduğu söylenebilir $(\mathrm{p}<0.05)$.

- Dilsel zeka puanları ile diğer zeka puanları arasındaki ilişki incelendiğinde, en yüksek korelasyon katsayısı sosyal zekada olduğundan $(\mathrm{r}=0.59)$, dilsel zeka ile en fazla sosyal zeka arasında anlamlı bir ilişki olduğu söylenebilir $(\mathrm{p}<0.05)$.

- Sosyal zeka puanları ile diğer zeka puanları arasındaki ilişki incelendiğinde, en yüksek korelasyon katsayısı içsel zekada olduğundan ( $\mathrm{r}=0.66)$, sosyal zeka ile en fazla içsel zeka arasında anlamlı bir ilişki olduğu söylenebilir $(\mathrm{p}<0.05)$.

- İçsel zeka puanları ile diğer zeka puanları arasındaki ilişki incelendiğinde, en yüksek korelasyon katsayısı sosyal zekada olduğundan ( $r=0.66)$, içsel zeka ile en fazla sosyal zeka arasında anlamlı bir ilişki olduğu söylenebilir $(\mathrm{p}<0.05)$.

- Doğacı zeka puanları ile diğer zeka puanları arasındaki ilişki incelendiğinde, en yüksek korelasyon katsayısı uzamsal zekada olduğundan $(\mathrm{r}=0.50)$, doğacı zeka ile en fazla uzamsal zeka arasında anlamlı bir ilişki olduğu söylenebilir $(\mathrm{p}<0.05)$.

- MSGSÜ öğrencilerinin zeka puanları arasında yapılan Pearson Korelasyon Analizi sonuçları Tablo 7'de sunulmuştur. 
Tablo 7. MSGSÜ öğrencilerinin zeka puanları arasında yapılan Pearson Korelasyon Analizi sonuçları

\section{Correlations}

\begin{tabular}{|c|c|c|c|c|c|c|c|c|c|c|}
\hline & & $\mathbf{N}$ & $\begin{array}{l}\text { Müziksel } \\
\text { Zeka }\end{array}$ & $\begin{array}{l}\text { Bedensel } \\
\text { Zeka }\end{array}$ & $\begin{array}{l}\text { Matematiksel } \\
\text { Zeka }\end{array}$ & $\begin{array}{l}\text { Uzamsal } \\
\text { Zeka }\end{array}$ & $\begin{array}{r}\text { Dilsel } \\
\text { Zeka }\end{array}$ & $\begin{array}{c}\text { Sosyal } \\
\text { Zeka }\end{array}$ & $\begin{array}{l}\text { İçsel } \\
\text { Zeka }\end{array}$ & $\begin{array}{l}\text { Doğacı } \\
\text { Zeka }\end{array}$ \\
\hline \multirow[t]{2}{*}{$\begin{array}{l}\text { Müziksel } \\
\text { Zeka }\end{array}$} & $\begin{array}{l}\text { Pearson } \\
\text { Correlation }\end{array}$ & 139 & 1 & $0,18^{*}$ & $0,22^{*}$ & $0,31^{*}$ & $0,41^{*}$ & $0,30^{*}$ & $0,28^{*}$ & 0,12 \\
\hline & $\begin{array}{l}\text { Sig. } \\
\text { (2-tailed) }\end{array}$ & & & 0,04 & 0,01 & 0,00 & 0,00 & 0,00 & 0,00 & 0,15 \\
\hline \multirow[t]{2}{*}{$\begin{array}{l}\text { Bedensel } \\
\text { Zeka }\end{array}$} & $\begin{array}{l}\text { Pearson } \\
\text { Correlation }\end{array}$ & 139 & & 1 & $0,22^{*}$ & $0,39^{*}$ & $0,23^{*}$ & $0,25^{*}$ & $0,31^{*}$ & $0,25^{*}$ \\
\hline & $\begin{array}{l}\text { Sig. } \\
\text { (2-tailed) }\end{array}$ & & & & 0,01 & 0,00 & 0,01 & 0,003 & 0,00 & 0,00 \\
\hline \multirow[t]{2}{*}{$\begin{array}{l}\text { Matematiksel } \\
\text { Zeka }\end{array}$} & $\begin{array}{l}\text { Pearson } \\
\text { Correlation }\end{array}$ & 139 & & & 1 & $0,46^{*}$ & $0,52^{*}$ & $0,43^{*}$ & $0,43^{*}$ & 0,15 \\
\hline & $\begin{array}{l}\text { Sig. } \\
\text { (2-tailed) }\end{array}$ & & & & & 0,00 & 0,00 & 0,00 & 0,00 & 0,08 \\
\hline \multirow[t]{2}{*}{$\begin{array}{l}\text { Uzamsal } \\
\text { Zeka }\end{array}$} & $\begin{array}{l}\text { Pearson } \\
\text { Correlation }\end{array}$ & 139 & & & & 1 & $0,40^{*}$ & $0,35^{*}$ & $0,46^{*}$ & $0,39^{*}$ \\
\hline & $\begin{array}{l}\text { Sig. } \\
\text { (2-tailed) }\end{array}$ & & & & & & 0,00 & 0,00 & 0,00 & 0,00 \\
\hline \multirow[t]{2}{*}{ Dilsel Zeka } & $\begin{array}{l}\text { Pearson } \\
\text { Correlation }\end{array}$ & 139 & & & & & 1 & $0,46^{*}$ & $0,46^{*}$ & $0,32^{*}$ \\
\hline & $\begin{array}{l}\text { Sig. } \\
\text { (2-tailed) }\end{array}$ & & & & & & & 0,00 & 0,00 & 0,00 \\
\hline \multirow[t]{2}{*}{ Sosyal Zeka } & $\begin{array}{l}\text { Pearson } \\
\text { Correlation }\end{array}$ & 139 & & & & & & 1 & $0,55^{*}$ & $0,18^{*}$ \\
\hline & $\begin{array}{l}\text { Sig. } \\
\text { (2-tailed) }\end{array}$ & & & & & & & & 0,00 & 0,04 \\
\hline \multirow[t]{2}{*}{ İçsel Zeka } & $\begin{array}{l}\text { Pearson } \\
\text { Correlation }\end{array}$ & 139 & & & & & & & 1 & $0,28^{*}$ \\
\hline & $\begin{array}{l}\text { Sig. } \\
\text { (2-tailed) }\end{array}$ & & & & & & & & & 0,00 \\
\hline \multirow[t]{2}{*}{ Doğacı Zeka } & $\begin{array}{l}\text { Pearson } \\
\text { Correlation }\end{array}$ & 139 & & & & & & & & 1 \\
\hline & $\begin{array}{l}\text { Sig. } \\
\text { (2-tailed) }\end{array}$ & & & & & & & & & \\
\hline
\end{tabular}

*. Correlation is significant at the 0.05 level (2-tailed). 
MSGSÜ öğrencilerinin zeka puanları arasında yapılan Pearson Korelasyon Analizi sonuçlarına göre,

- Müziksel zeka puanları ile diğer zeka puanları arasındaki ilişki incelendiğinde, en yüksek korelasyon katsayısı dilsel zekada olduğundan $(\mathrm{r}=0.41)$, müziksel zeka ile en fazla dilsel zeka arasında anlamlı bir ilişki olduğu söylenebilir $(\mathrm{p}<0.05)$.

- Bedensel zeka puanları ile diğer zeka puanları arasındaki ilişki incelendiğinde, en yüksek korelasyon katsayısı uzamsal zekada olduğundan $(\mathrm{r}=0.39)$, bedensel zeka ile en fazla uzamsal zeka arasında anlamlı bir ilişki olduğu söylenebilir $(\mathrm{p}<0.05)$.

- Matematiksel zeka puanları ile diğer zeka puanları arasındaki ilişki incelendiğinde, en yüksek korelasyon katsayısı dilsel zekada olduğundan $(\mathrm{r}=0.52)$, matematiksel zeka ile en fazla dilsel zeka arasında anlamlı bir ilişki olduğu söylenebilir $(\mathrm{p}<0.05)$.

- Uzamsal zeka puanları ile diğer zeka puanları arasındaki ilişki incelendiğinde, en yüksek korelasyon katsayısı matematiksel ve içsel zekalarda olduğundan $(\mathrm{r}=0.46)$, uzamsal zeka ile en fazla matematiksel ve içsel zeka arasında anlamlı bir ilişki olduğu söylenebilir $(\mathrm{p}<0.05)$.

- Dilsel zeka puanları ile diğer zeka puanları arasındaki ilişki incelendiğinde, en yüksek korelasyon katsayısı matematiksel zekada olduğundan $(\mathrm{r}=0.52)$, dilsel zeka ile en fazla matematiksel zeka arasında anlamlı bir ilişki olduğu söylenebilir $(\mathrm{p}<0.05)$.

- Sosyal zeka puanları ile diğer zeka puanları arasındaki ilişki incelendiğinde, en yüksek korelasyon katsayısı içsel zekada olduğundan ( $\mathrm{r}=0.55)$, sosyal zeka ile en fazla içsel zeka arasında anlamlı bir ilişki olduğu söylenebilir $(\mathrm{p}<0.05)$.

- İçsel zeka puanları ile diğer zeka puanları arasındaki ilişki incelendiğinde, en yüksek korelasyon katsayısı sosyal zekada olduğundan ( $\mathrm{r}=0.55)$, içsel zeka ile en fazla sosyal zeka arasında anlamlı bir ilişki olduğu söylenebilir $(\mathrm{p}<0.05)$.

- Doğacı zeka puanları ile diğer zeka puanları arasındaki ilişki incelendiğinde, en yüksek korelasyon katsayısı uzamsal zekada olduğundan $(\mathrm{r}=0.39)$, doğacı zeka ile en fazla uzamsal zeka arasında anlamlı bir ilişki olduğu söylenebilir $(\mathrm{p}<0.05)$. 


\section{Öğrencilerin Cinsiyetleri ile Çoklu Zeka Alanları Arasındaki İlişki}

Mimarlık öğrencilerinin cinsiyet ve çoklu zeka alanları arasındaki ilişki hem tüm öğrenciler hem de üniversiteler düzeyinde incelenmiştir. Öğrencilerin cinsiyetleri ile çoklu zeka alanları arasındaki ilişkinin belirlenebilmesi için bağımsız örneklemler t-testi yapılmıştır. Tablo 8'de öğrencilerin cinsiyete göre ortalama çoklu zeka alanları puanları, Ek 1'de ise cinsiyet değişkenine göre zeka puanları arasında yapılan bağımsız örneklemler t- testi sonuçları verilmiştir.

Tablo 8. Cinsiyete Göre Ortalama Çoklu Zeka Alanları Puanları

\begin{tabular}{|c|c|c|c|c|c|}
\hline & Cinsiyet & $\mathbf{N}$ & Ortalama & $\begin{array}{l}\text { Standart } \\
\text { Sapma }\end{array}$ & $\begin{array}{l}\text { Ortalamaların } \\
\text { Standart Hatası }\end{array}$ \\
\hline \multirow[t]{2}{*}{ Sosyal Zeka } & Erkek & 120 & 0.614 & 0.158 & 0.014 \\
\hline & Kız & 145 & 0.625 & 0.120 & 0.010 \\
\hline \multirow[t]{2}{*}{ İçsel Zeka } & Erkek & 120 & 0.606 & 0.204 & 0.019 \\
\hline & Kız & 145 & 0.616 & 0.183 & 0.015 \\
\hline \multirow{2}{*}{$\begin{array}{l}\text { Matematiksel } \\
\text { Zeka }\end{array}$} & Erkek & 120 & 0.615 & 0.157 & 0.014 \\
\hline & $\mathbf{K} \mathbf{z z}$ & 145 & 0.598 & 0.141 & 0.012 \\
\hline \multirow{2}{*}{$\begin{array}{l}\text { Müziksel } \\
\text { Zeka }\end{array}$} & Erkek & 120 & 0.509 & 0.191 & 0.017 \\
\hline & Kız & 145 & 0.625 & 0.157 & 0.013 \\
\hline \multirow[t]{2}{*}{ Uzamsal Zeka } & Erkek & 120 & 0.480 & 0.190 & 0.017 \\
\hline & $\mathbf{K} \mathbf{z Z}$ & 145 & 0.490 & 0.174 & 0.014 \\
\hline \multirow[t]{2}{*}{ Bedensel Zeka } & Erkek & 120 & 0.489 & 0.181 & 0.016 \\
\hline & Kız & 145 & 0.438 & 0.169 & 0.014 \\
\hline \multirow[t]{2}{*}{ Dilsel Zeka } & Erkek & 120 & 0.461 & 0.173 & 0.016 \\
\hline & Kiz & 145 & 0.455 & 0.147 & 0.012 \\
\hline \multirow[t]{2}{*}{ Doğacı Zeka } & Erkek & 120 & 0.403 & 0.185 & 0.017 \\
\hline & Kız & 145 & 0.401 & 0.189 & 0.016 \\
\hline
\end{tabular}

Tablo 8 incelendiğinde; kı öğrencilerin sosyal, içsel, müziksel ve uzamsal zeka puan ortalamalarının daha yüksek olduğu, erkek öğrencilerin ise matematiksel, bedensel, dilsel ve doğacı zeka puan ortalamalarının daha yüksek olduğu görülmüsstür. Şekil 3'te Tablo 8 'in grafik olarak ifadesi sunulmuştur. 


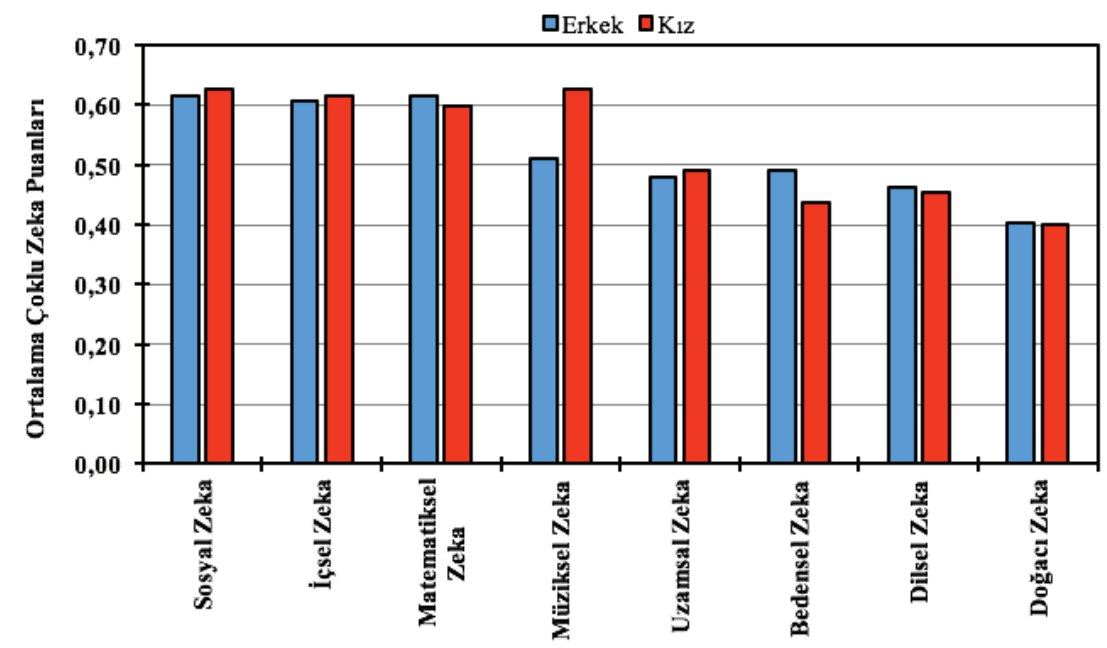

Şekil 3. Cinsiyete Göre Ortalama Çoklu Zeka Alanları Puanları

Cinsiyet değişkenine göre zeka puanları arasında yapılan bağımsız örneklemler t-testi sonuçlarına göre (Ek 1); müziksel ve bedensel zeka alanlarında cinsiyete göre puan farkı olması anlamlıdır $(\mathrm{p}<0.05)$. Diğer alanlarda ise cinsiyete göre puan fark1 olması istatistiksel olarak anlamlı değildir ( $>0.05)$. Müziksel zeka alanında kız ögrenciler, bedensel zeka alanında ise erkek öğrenciler daha başarılıdır.

FSMVÜ mimarlık öğrencilerinin cinsiyet ve çoklu zeka alanları arasındaki ilişki incelenmiş, Tablo 9'da FSMVÜ öğrencilerinin cinsiyete göre ortalama çoklu zeka alanları puanları verilmiştir.

Tablo 9. FSMVÜ öğrencilerinin cinsiyete göre ortalama çoklu zeka alanları puanları

\begin{tabular}{|l|l|l|c|c|c|}
\hline & Cinsiyet & $\mathbf{N}$ & Ortalama & $\begin{array}{c}\text { Standart } \\
\text { Sapma }\end{array}$ & $\begin{array}{c}\text { Ortalamaların } \\
\text { Standart Hatası }\end{array}$ \\
\hline \multirow{2}{*}{ Sosyal Zeka } & Erkek & 24 & 0.650 & 0.179 & 0.037 \\
\cline { 2 - 6 } & $\mathbf{K u z}$ & 22 & 0.622 & 0.115 & 0.024 \\
\hline \multirow{2}{*}{ İsel Zeka } & Erkek & 24 & 0.620 & 0.224 & 0.046 \\
\cline { 2 - 6 } & Kiz & 22 & 0.643 & 0.202 & 0.043 \\
\hline \multirow{2}{*}{$\begin{array}{l}\text { Matematiksel } \\
\text { Zeka }\end{array}$} & Erkek & 24 & 0.605 & 0.165 & 0.034 \\
\cline { 2 - 6 } & $\mathbf{K} \mathbf{z}$ & 22 & 0.556 & 0.123 & 0.026 \\
\hline
\end{tabular}




\begin{tabular}{|l|l|c|c|c|c|}
\hline Müziksel Zeka & Erkek & 24 & 0.548 & 0.182 & 0.037 \\
\cline { 2 - 6 } & Kız & 22 & 0.616 & 0.179 & 0.038 \\
\hline \multirow{2}{*}{ Uzamsal Zeka } & Erkek & 24 & 0.487 & 0.175 & 0.036 \\
\cline { 2 - 6 } & Kız & 22 & 0.500 & 0.178 & 0.038 \\
\hline \multirow{2}{*}{ Bedensel Zeka } & Erkek & 24 & 0.547 & 0.184 & 0.038 \\
\cline { 2 - 6 } & Kız & 22 & 0.451 & 0.165 & 0.035 \\
\hline \multirow{2}{*}{ Dilsel Zeka } & Erkek & 24 & 0.510 & 0.186 & 0.038 \\
\cline { 2 - 6 } & Kız & 22 & 0.496 & 0.137 & 0.029 \\
\hline \multirow{2}{*}{ Doğacı Zeka } & Erkek & 24 & 0.403 & 0.203 & 0.041 \\
\cline { 2 - 6 } & Kız & 22 & 0.439 & 0.230 & 0.049 \\
\hline
\end{tabular}

Tablo 9 incelendiğinde; FSMVÜ'deki kızların içsel, müziksel, uzamsal ve doğacı zeka puan ortalamalarının daha yüksek olduğu, erkeklerin ise sosyal, matematiksel, bedensel ve dilsel zeka puan ortalamalarının daha yüksek olduğu görülmüştür. Şekil 4'te Tablo 9'un grafik olarak ifadesi sunulmuştur.

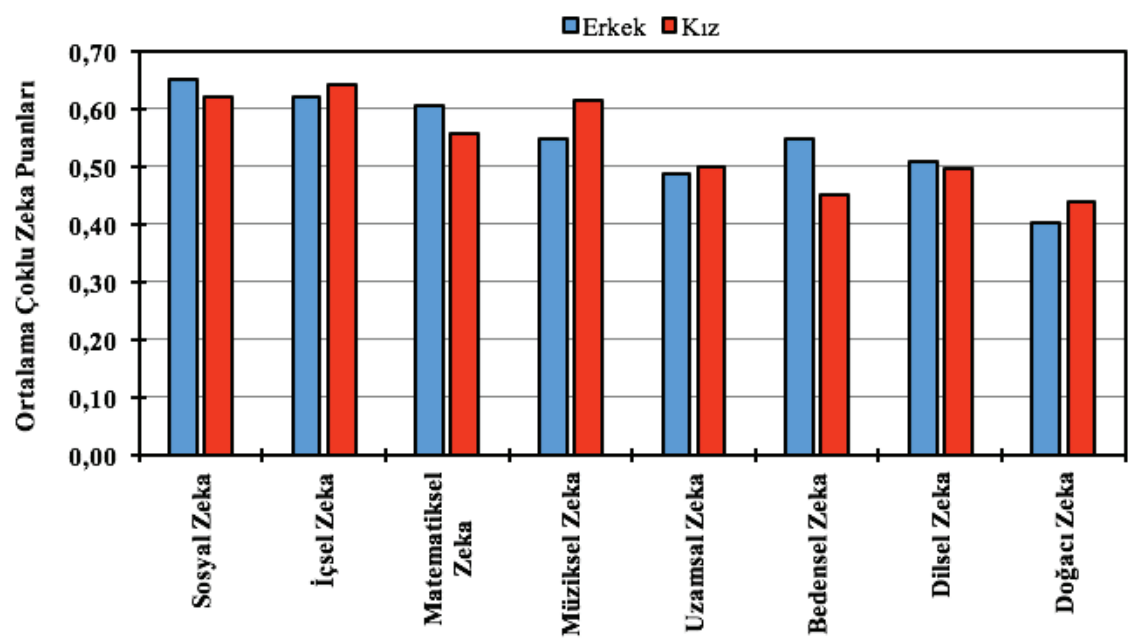

Şekil 4. FSMVÜ öğrencilerinin cinsiyete göre ortalama çoklu zeka alanları puanları

Cinsiyet değişkenine göre FSMVÜ öğrencilerinin zeka puanları arasında yapılan bağımsız örneklemler t-testi sonuçlarına göre (Ek 2) puan farkı olmasının istatistiksel olarak anlamlı olmadiğı ortaya çıkmıştır ( $>0.05)$. 
YTÜ mimarlık öğrencilerinin cinsiyet ve çoklu zeka alanları arasındaki ilişki incelenmiş, Tablo 10'da YTÜ öğrencilerinin cinsiyete göre ortalama çoklu zeka alanları puanları verilmiştir.

Tablo 10. YTÜ öğrencilerinin cinsiyete göre ortalama çoklu zeka alanları puanları

\begin{tabular}{|c|c|c|c|c|c|}
\hline & Cinsiyet & $\mathbf{N}$ & Ortalama & $\begin{array}{c}\text { Standart } \\
\text { Sapma }\end{array}$ & $\begin{array}{c}\text { Ortalamaların } \\
\text { Standart } \\
\text { Hatası }\end{array}$ \\
\hline \multirow[t]{2}{*}{ Sosyal Zeka } & Erkek & 39 & 0.622 & 0.156 & 0.025 \\
\hline & $\mathbf{K i z}$ & 41 & 0.652 & 0.108 & 0.017 \\
\hline \multirow[t]{2}{*}{ İçsel Zeka } & Erkek & 39 & 0.666 & 0.201 & 0.032 \\
\hline & $\mathbf{K i z}$ & 41 & 0.667 & 0.153 & 0.024 \\
\hline \multirow{2}{*}{$\begin{array}{l}\text { Matematiksel } \\
\text { Zeka }\end{array}$} & Erkek & 39 & 0.651 & 0.152 & 0.024 \\
\hline & Kız & 41 & 0.643 & 0.126 & 0.020 \\
\hline \multirow[t]{2}{*}{ Müziksel Zeka } & Erkek & 39 & 0.481 & 0.176 & 0.028 \\
\hline & $\mathbf{K i z}$ & 41 & 0.605 & 0.165 & 0.026 \\
\hline \multirow[t]{2}{*}{ Uzamsal Zeka } & Erkek & 39 & 0.536 & 0.195 & 0.031 \\
\hline & $\mathbf{K} \mathbf{z z}$ & 41 & 0.543 & 0.163 & 0.025 \\
\hline \multirow[t]{2}{*}{ Bedensel Zeka } & Erkek & 39 & 0.478 & 0.184 & 0.029 \\
\hline & $\mathbf{K i z}$ & 41 & 0.462 & 0.182 & 0.028 \\
\hline \multirow[t]{2}{*}{ Dilsel Zeka } & Erkek & 39 & 0.453 & 0.168 & 0.027 \\
\hline & Kız & 41 & 0.436 & 0.148 & 0.023 \\
\hline \multirow[t]{2}{*}{ Doğacı Zeka } & Erkek & 39 & 0.402 & 0.183 & 0.029 \\
\hline & Kız & 41 & 0.418 & 0.172 & 0.027 \\
\hline
\end{tabular}

Tablo 10 incelendiğinde; YTÜ'deki kız öğrencilerin sosyal, içsel, müziksel, uzamsal ve doğacı zeka puan ortalamalarının daha yüksek olduğu, erkek öğrencilerin ise matematiksel, bedensel ve dilsel zeka puan ortalamalarının daha yüksek olduğu görülmüştür. Şekil 5'te Tablo 10'un grafik olarak ifadesi sunulmuştur. 


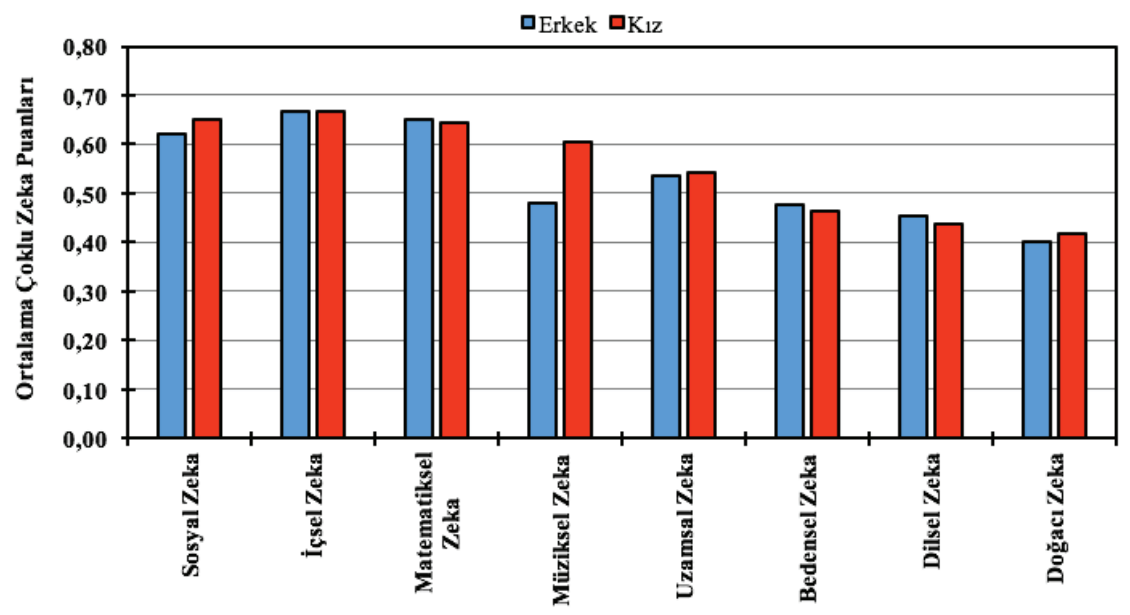

Şekil 5. YTÜ öğrencilerinin cinsiyete göre ortalama çoklu zeka alanları puanları

Cinsiyet değişkenine göre YTÜ öğrencilerinin zeka puanları arasında yapılan bağımsız örneklemler t-testi sonuçlarına göre (Ek 3); müziksel zeka alanında cinsiyete göre puan farkı olması anlamlıdır $(\mathrm{p}<0.05)$. Diğer alanlarda ise cinsiyete göre puan farkı olması istatistiksel olarak anlamlı değildir ( $>>0.05)$. YTÜ'de müziksel zeka alanında kız ögrenciler daha başarılıdır.

MSGSÜ mimarlık öğrencilerinin cinsiyet ve çoklu zeka alanları arasındaki ilişki incelenmiş, Tablo 11'de MSGSÜ öğrencilerinin cinsiyete göre ortalama çoklu zeka alanları puanları verilmiştir.

Tablo 11. MSGSÜ öğrencilerinin cinsiyete göre ortalama çoklu zeka alanları puanları

\begin{tabular}{|l|l|c|c|c|c|}
\hline & Cinsiyet & $\mathbf{N}$ & Ortalama & $\begin{array}{c}\text { Standart } \\
\text { Sapma }\end{array}$ & $\begin{array}{c}\text { Ortalamaların } \\
\text { Standart Hatası }\end{array}$ \\
\hline Sosyal Zeka & Erkek & 57 & 0.593 & 0.150 & 0.020 \\
\cline { 2 - 6 } & Kız & 82 & 0.613 & 0.126 & 0.014 \\
\hline \multirow{2}{*}{ İsel Zeka } & Erkek & 57 & 0.559 & 0.188 & 0.025 \\
\cline { 2 - 6 } & Kız & 82 & 0.584 & 0.187 & 0.021 \\
\hline $\begin{array}{l}\text { Matematiksel } \\
\text { Zeka }\end{array}$ & Erkek & 57 & 0.594 & 0.156 & 0.021 \\
\cline { 2 - 6 } & Kiz & 82 & 0.588 & 0.149 & 0.016 \\
\hline
\end{tabular}




\begin{tabular}{|l|l|r|r|r|l|}
\hline Müziksel Zeka & Erkek & 57 & 0.512 & 0.203 & 0.027 \\
\cline { 2 - 6 } & Kız & 82 & 0.638 & 0.147 & 0.016 \\
\hline \multirow{2}{*}{ Uzamsal Zeka } & Erkek & 57 & 0.439 & 0.185 & 0.024 \\
\cline { 2 - 6 } & Kız & 82 & 0.461 & 0.174 & 0.019 \\
\hline \multirow{2}{*}{ Bedensel Zeka } & Erkek & 57 & 0.472 & 0.174 & 0.023 \\
\cline { 2 - 6 } & Kız & 82 & 0.423 & 0.164 & 0.018 \\
\hline \multirow{2}{*}{ Dilsel Zeka } & Erkek & 57 & 0.446 & 0.169 & 0.022 \\
\cline { 2 - 6 } & Kız & 82 & 0.453 & 0.148 & 0.016 \\
\hline \multirow{2}{*}{ Doğacı Zeka } & Erkek & 57 & 0.403 & 0.182 & 0.024 \\
\cline { 2 - 6 } & Kız & 82 & 0.383 & 0.185 & 0.020 \\
\hline
\end{tabular}

Tablo 11 incelendiğinde; MSGSÜ'deki kız öğrencilerin sosyal, içsel, müziksel, uzamsal ve dilsel zeka puan ortalamalarının daha yüksek olduğu, erkek öğrencilerin ise matematiksel, bedensel ve doğacı zeka puan ortalamalarının daha yüksek olduğu görülmüştür. Şekil 6'da Tablo 11'in grafik olarak ifadesi sunulmuştur.

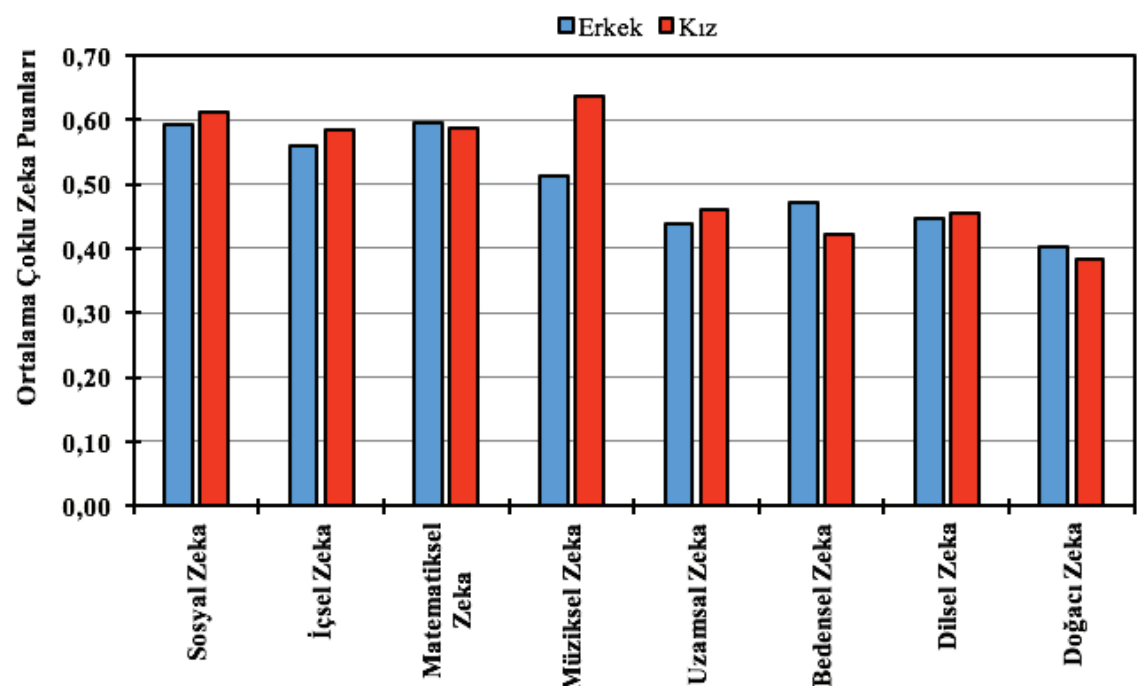

Şekil 6. MSGSÜ öğrencilerinin cinsiyete göre ortalama çoklu zeka alanları puanları

Cinsiyet değişkenine göre MSGSÜ öğrencilerinin zeka puanları arasında yapılan bağımsız örneklemler t-testi sonuçlarına göre (Ek 4); müziksel zeka ala- 
nında cinsiyete göre puan farkı olması anlamlıdır $(\mathrm{p}<0.05)$. Diğer alanlarda ise cinsiyete göre puan farkı olması istatistiksel olarak anlamlı değildir ( $\mathrm{p}>0.05)$. MSGSÜ'de müziksel zeka alanında kız ögrrenciler daha başarılıdır.

Tablo 12'de üç üniversitedeki mimarlık öğrencilerinin cinsiyete göre ortalama çoklu zeka alanları puanları birarada verilmiştir. Şekil 7'de Tablo 12'nin grafik olarak ifadesi sunulmuştur.

Tablo 12. Üç üniversitedeki mimarlık öğrencilerinin cinsiyete göre ortalama çoklu zeka alanları puanları

\begin{tabular}{|c|c|c|c|c|}
\hline & Cinsiyet & $\begin{array}{c}\text { FSMVÜ } \\
\text { Ortalama Zeka } \\
\text { Puanı }\end{array}$ & $\begin{array}{c}\text { YTÜ } \\
\text { Ortalama Zeka } \\
\text { Puanı }\end{array}$ & $\begin{array}{c}\text { MSGSÜ } \\
\text { Ortalama Zeka } \\
\text { Puanı }\end{array}$ \\
\hline \multirow[t]{2}{*}{ Sosyal Zeka } & Erkek & 0.650 & 0.622 & 0.593 \\
\hline & $\mathrm{K} 1 \mathrm{z}$ & 0.622 & 0.652 & 0.613 \\
\hline \multirow[t]{2}{*}{ İçsel Zeka } & Erkek & 0.620 & 0.666 & 0.559 \\
\hline & $\mathrm{K} 1 \mathrm{z}$ & 0.643 & 0.667 & 0.584 \\
\hline \multirow{2}{*}{$\begin{array}{l}\text { Matematiksel } \\
\text { Zeka }\end{array}$} & Erkek & 0.605 & 0.651 & 0.594 \\
\hline & $\mathrm{K} 1 \mathrm{z}$ & 0.556 & 0.643 & 0.588 \\
\hline \multirow{2}{*}{$\begin{array}{l}\text { Müziksel } \\
\text { Zeka }\end{array}$} & Erkek & 0.548 & 0.481 & 0.512 \\
\hline & Kız & 0.616 & 0.605 & 0.638 \\
\hline \multirow{2}{*}{$\begin{array}{l}\text { Uzamsal } \\
\text { Zeka }\end{array}$} & Erkek & 0.487 & 0.536 & 0.439 \\
\hline & $\mathrm{K} 1 \mathrm{z}$ & 0.500 & 0.543 & 0.461 \\
\hline \multirow{2}{*}{$\begin{array}{l}\text { Bedensel } \\
\text { Zeka }\end{array}$} & Erkek & 0.547 & 0.478 & 0.472 \\
\hline & $\mathrm{K} 1 \mathrm{z}$ & 0.451 & 0.462 & 0.423 \\
\hline \multirow[t]{2}{*}{ Dilsel Zeka } & Erkek & 0.510 & 0.453 & 0.446 \\
\hline & $\mathrm{K} 1 \mathrm{z}$ & 0.496 & 0.436 & 0.453 \\
\hline \multirow[t]{2}{*}{ Doğacı Zeka } & Erkek & 0.403 & 0.402 & 0.403 \\
\hline & Kız & 0.439 & 0.418 & 0.383 \\
\hline
\end{tabular}




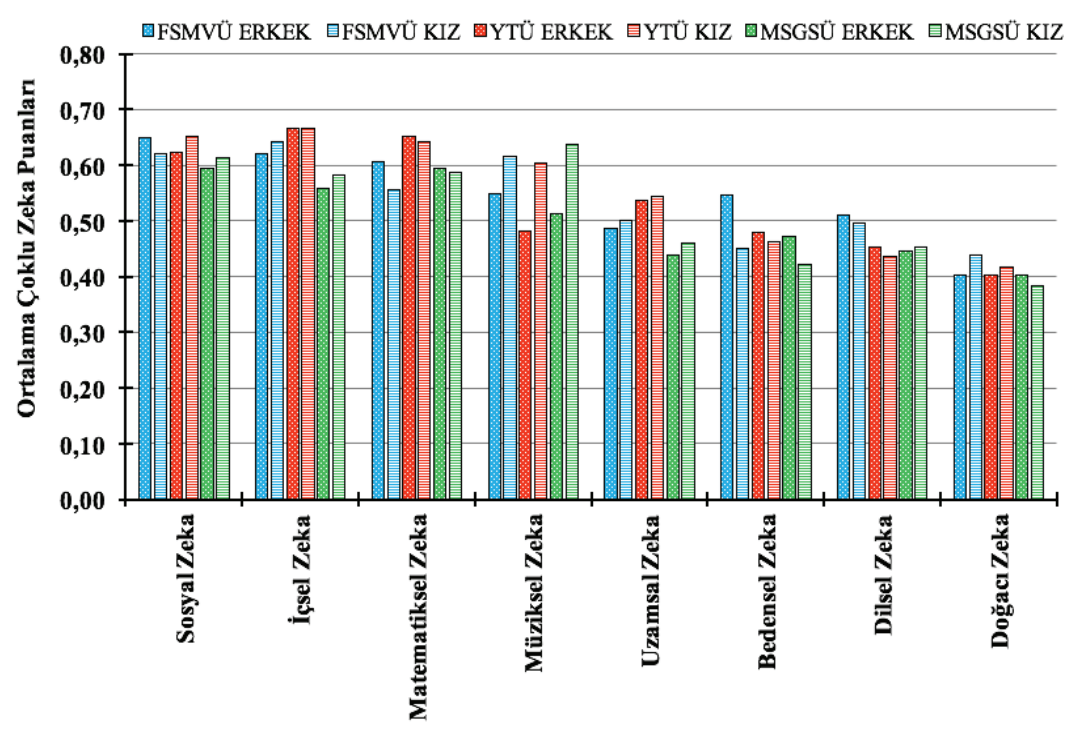

Şekil 7. Üç üniversitedeki mimarlık öğrencilerinin cinsiyete göre ortalama çoklu zeka alanları puanları

Tablo 12 incelendiğinde aşağıdaki sonuçlara ulaşılmıştır;

- Üç üniversitede de erkeklerin matematiksel ortalama zeka puanı daha fazladır. Buna rağmen yapılan bağımsız örneklemler t-testi sonuçlarına göre üç üniversite için (Ek 2, Ek 3, Ek 4) bu sonuçlar anlamlı değildir $(\mathrm{p}>0.05)$.

- Üç üniversitede de kızların müziksel ortalama zeka puanı daha fazladır. Ancak üç üniversite için ayrı ayrı yapılan bağımsız örneklemler t-testi sonuçlarına göre kızların müziksel ortalama zeka puanlarının fazla olmas1 YTÜ (Ek 3) ve MSGSÜ (Ek 4) için istatistiksel açıdan anlamlı iken $(\mathrm{p}<0.05)$, FSMVÜ (Ek 2) için istatistiksel açıdan anlamlı değildir $(\mathrm{p}>0.05)$.

- Üç üniversitede de kızların uzamsal ortalama zeka puanı daha fazladır. Buna rağmen yapılan bağımsız örneklemler t-testi sonuçlarına göre üç üniversite için (Ek 2, Ek 3, Ek 4) bu sonuçlar istatistiksel açıdan anlamlı değildir $(\mathrm{p}>0.05)$.

- Üç üniversitede de erkeklerin bedensel ortalama zeka puanı daha fazladır. Buna rağmen üç üniversite için ayrı ayrı yapılan bağımsız örneklemler ttesti sonuçlarına göre (Ek 2, Ek 3, Ek 4) bu sonuçlar istatistiksel açıdan anlamlı değildir $(\mathrm{p}>0.05)$. 


\section{Sonuç ve Öneriler}

Değerlendirmeye alınan 265 anket katılımcısından 145 (\%55)'i kız, 120 (\%45)'si erkektir. Çalışmanın bulguları, mimarlık öğrencilerinin en baskın zeka alanının sosyal zeka olduğunu göstermiştir. Uzamsal zeka ise beşinci sırada yer almıştır (Tablo 2).

Sosyal zeka, bir insanın diğer insanlardaki yüz ifadelerine, seslere ve mimiklere duyarlılığı ve diğer insanlardaki farklı özelliklerin farkına vararak en iyi şekilde analiz etme, yorumlama ve değerlendirme yetenekleri olarak ifade edilir. $\mathrm{Bu}$ nedenle sosyal zekası güçlü olan kimseler bir grup içerisinde grup üyeleriyle işbirliği yapma, onlarla uyum içinde çalışma ve bu kişilerle etkili olarak sözlü ve sözsüz iletişim kurma yeteneklerine sahiptir ${ }^{33}$. Mimarlık öğrencilerinin sosyal zeka alanlarının baskın olması, grup çalışmalarına uyum sağlamakta zorlanmayacaklarını göstermektedir. Böylece öğrencilerin sosyal zekalarının baskın olmasından, mimarlık eğitimi alanında faydalanılabilir.

Uzamsal zeka ise görsel dünyayı doğru biçimde algılamak, başlangıçtaki alg1 üzerinde değişim ve dönüşümler yapabilmek, görsel deneyimi fiziksel uyarıcının yokluğunda dahi yeniden üretebilmek olarak tanımlanır ${ }^{34}$. Çoklu zeka alanlarının genellikle bir arada, belli bir uyum ve etkileşim içinde çalıştığ ifade edilir ${ }^{35}$. Mimari Tasarım eğitimi ve sonrasındaki meslek hayatı ise pek çok zeka alanının beraber çalışmasına gereksinim duyar. Ancak mimari tasarım eğitiminin temel zeka biçimlerini mantıksal-matematiksel zekanın devamı ve uzamsal zeka ile birlikte düşünülmesi oluşturur ${ }^{36}$. Dolayısıyla uzamsal zeka alanı mimarlık eğitimi için önem taşımaktadır.

Harvard Üniversitesi öğretim görevlisi Bruce Toff, öğrencilerin güçlü ve zayıf yönleri arasında köprü kuracak etkinliklerin sınıfta kullanımının, onların zayıf özelliklerinin güçlendirilmesine katkıda bulunacağını belirtmektedir ${ }^{37}$. Bu nedenle uzamsal zekayı güçlendirmek için, öğrencilerin güçlü yönleri olan sosyal zeka alanını kullanarak, konuya dikkatlerini çekecek etkinlikler düzenlenebilir. İzlenen her hedefin hayata geçirilmesinde kullanılacak bir zekalar kümesi

33 İflazoğlu, a.g.e., s.24.

34 Gardner, a.g.e., Çoklu Zeka Kuramı: Zihin Çerçeveleri, s.246.

35 Saban, a.g.e., Çoklu Zeka Kuramı ve Türk Eğitim Sistemine Yansıması, s.10.

36 Sağıroğlu, a.g.e., s.81.

37 Süleyman Tarman, "Program Geliştirme Sürecinde Çoklu Zeka Kuramının Yeri”, (Yayımlanmamış Yüksek Lisans Tezi), Hacettepe Üniversitesi Sosyal Bilimler Enstitüsü, Ankara, 1999, s.107. 
olduğundan ${ }^{38}$, bu etkinlikler aynı zamanda birden fazla zekayı harekete geçirecek şekilde düzenlendiğinde, aynı zamanda öğrenmeyi de pekiştirebilecektir.

Çoklu zeka alanları ortalama puanları üniversiteler düzeyinde incelendiğinde (Tablo 4);

- FSMVÜ mimarlık öğrencilerinin en baskın ilk üç zeka alanının sırasıyla sosyal, içsel ve matematiksel,

- YTÜ mimarlık öğrencilerinin en baskın ilk üç zeka alanının sırasıyla içsel, matematiksel ve sosyal,

- MSGSÜ mimarlık öğrencilerinin en baskın ilk üç zeka alanının sırasıyla sosyal, matematiksel ve müziksel zekalar olduğu ortaya çıkmıştır.

$\mathrm{Bu}$ bulgulara göre sosyal ve matematiksel zekalar tüm öğrenciler düzeyinde olduğu gibi (Tablo 2), üniversiteler düzeyinde de en baskın üç zeka arasında yer almaktadır (Tablo 4). Türk orta öğretim sisteminde, öğrencilerin mantıksal-matematiksel zeka kullanımları gelişmektedir ${ }^{39}$. Bu nedenle matematiksel zekanın en baskın zekalar arasında yer alması beklenen bir durumdur.

Öğrencilerin uzamsal zeka sıralamaları ise şöyledir; FSMVÜ mimarlık öğrencileri için uzamsal zeka ortalama puanı 7. sırada, YTÜ ve MSGSÜ için 5. sıradadır. YTÜ ögrencilerinin mimarlık eğitimi için önemli olan uzamsal zeka ile matematiksel zeka alanlarındaki ortalama puanları diğer üniversitelerden daha fazladır.

Kıyaslanan üç üniversitedeki mimarlık öğrencilerinin ortalama zeka puanları arasında ise benzerlikler bulunmaktadır (Tablo 4). Çoklu Zeka Ölçeği, çoğu mimarlık eğitiminin ilk yarıyılında olan mimarlık öğrencilerine uygulandığından, bu durumu öğrencilerin benzer bir eğitim altyapısıyla bölümlerine gelmesi ile açıklayabiliriz.

Zorunlu eğitim süreci 1997 yılında sekiz yıla çıkarılırken, lise eğitimi ise 2005 yılında dört yıla çıkarılmıştır ${ }^{40}$. Türk eğitim sisteminde, mantıksal-matematiksel zeka tabanına dayalı bir orta öğretim aşaması söz konusu olduğundan ${ }^{41}$, eğitimde diğer zeka alanlarına yeterince ağırlık verilmediği sonucu çıkarılabilir.

38 Gardner, a.g.e., Çoklu Zeka Kuramı: Zihin Çerçeveleri, s.546.

39 Sağıroğlu, a.g.e, s.81.

40 Hande Nalçakan - Çiğdem Polatoğlu, “Türkiye'deki ve Dünyadaki Mimarlık Eğitiminin Karşılaştırmalı Analizi İle Küreselleşmenin Mimarlık Eğitimine Etkisinin İrdelenmesi”, Megaron, YTÜ Mim. Fak. E-Dergisi, cilt 3, say1 1, 2008, s.90.

41 Sağıroğlu, a.g.e., s.78. 
Öğrenci, merkezi sınav sistemi ile isteyerek veya istemeyerek bölüme yönlendirilmektedir ${ }^{42}$. Dolayısıyla öğrenciler yetenekleri paralelinde bir eğitim altyapısı sağlayamayan, mantıksal-matematiksel zeka tabanına dayalı lisans öncesi eğitim aşamasının ardından merkezi sınav sistemi vasıtasıyla lisans eğitimine geçiş yapmaktadır. Amerika ve Avrupa'da ise "öğrenciler ortaokuldan itibaren yönlendirilerek, isteklerine, becerilerine uygun liseye giderler ve üniversiteye geldiklerinde temel altyapıyı almış olurlar’"33.

Mimarlık eğitiminde, üç boyutlu algılama, düşünme ve tasarım becerilerinin geliştirildiği uzamsal zeka kullanımına geçiş olmaktadır ${ }^{44}$. Merkezi sınav sistemi ise yetenekleri ayrıştırmak konusunda yetersiz kaldığından, uzamsal zeka kullanımını gerektiren Mimarlık bölümlerinde benzer altyapıda yetişmiş, benzer bir öğrenci profili söz konusu olabilmektedir.

Mimarlık öğrencilerinin çoklu zeka puanları arasındaki ilişkinin belirlenebilmesi için; üç üniversitedeki öğrencilerin tümü, FSMVÜ öğrencileri, YTÜ öğrencileri ve MSGSÜ öğrencileri zeka puanları arasında Pearson Korelasyon Analizi yapılmıştır. Ortaya çıkan sonuçlara göre;

- Üç üniversitedeki öğrencilerin tümünün zeka puanları arasında yapılan Pearson Korelasyon Analizi sonuçları incelendiğinde (Tablo 3), en yüksek korelasyon katsayısına sahip olduğundan $(\mathrm{r}=0.58)$, en fazla içsel zeka ile sosyal zeka arasında anlamlı bir ilişki olduğu söylenebilir $(\mathrm{p}<0.05)$.

- FSMVÜ öğrencilerinin zeka puanları arasında yapılan Pearson Korelasyon Analizi sonuçları incelendiğinde (Tablo 5), en yüksek korelasyon katsayısına sahip olduğundan ( $\mathrm{r}=0.59)$, en fazla içsel zeka ile doğacı zeka arasında anlamlı bir ilişki olduğu söylenebilir $(\mathrm{p}<0.05)$.

- YTÜ öğrencilerinin zeka puanları arasında yapılan Pearson Korelasyon Analizi sonuçları incelendiğinde (Tablo 6), en yüksek korelasyon katsay1sına sahip olduğundan $(\mathrm{r}=0.66)$, en fazla sosyal zeka ile içsel zeka arasında anlamlı bir ilişki olduğu söylenebilir $(\mathrm{p}<0.05)$.

- MSGSÜ öğrencilerinin zeka puanları arasında yapılan Pearson Korelasyon Analizi sonuçları incelendiğinde (Tablo 7), en yüksek korelasyon katsayısına sahip olduğundan $(\mathrm{r}=0.55)$, en fazla sosyal zeka ile içsel zeka arasında anlamlı bir ilişki olduğu söylenebilir $(\mathrm{p}<0.05)$.

42 Nalçakan - Polatoğlu, a.g.e., s.99.

43 Nalçakan - Polatoğlu, a.g.e., s.99.

44 Sağıroğlu, a.g.e., s.78. 
Mimarlık öğrencilerinin cinsiyet ve çoklu zeka alanları arasındaki ilişki ise tüm ögrrenciler düzeyinde incelendiğinde (Tablo 8, Ek 1) elde edilen bulgulara göre müziksel zeka alanında kı öğrenciler, bedensel zeka alanında ise erkek öğrenciler daha başarılıdır.

Tüm mimarlık ögrrencileri düzeyinde ortalama zeka puanı ilk sırada yer alan sosyal zeka ile mimarlı eğitimi için önemli olan uzamsal zeka ortalama puanları cinsiyet açısından değerlendirildiğinde ise; klz ve erkek ögrencilerin ortalama zeka puanları arasında, sosyal ve uzamsal zekalar açısından anlamlı bir fark görülmemiştir $(p>0,05)$ (Ek 1).

Mimarlık öğrencilerinin cinsiyet ve çoklu zeka alanları arasındaki ilişki üniversiteler düzeyinde incelendiğinde ortaya çıkan bulgular şunlardır;

- FSMVÜ öğrencilerinin zeka alanları arasında cinsiyet değişkenine göre puan farkı olması istatistiksel olarak anlamlı değildir (Tablo 9, Ek 2).

- YTÜ'de müziksel zeka alanında kız ögrenciler erkek öğrencilerden daha başarılıdır (Tablo 10, Ek 3).

- MSGSÜ'de müziksel zeka alanında kız öğrenciler erkek ögrrencilerden daha başarılıdır (Tablo 11, Ek 4).

Üç üniversitedeki mimarlık öğrencilerinin cinsiyete göre ortalama çoklu zeka alanları puanları karşılaştırıldığında (Tablo 12, Şekil 7), üç üniversitede de erkeklerin matematiksel ve bedensel, kızların ise müziksel ve uzamsal zeka puan ortalamalarının daha fazla olduğu görülmüştür. Ancak, erkeklerin matematiksel ve bedensel zeka puan ortalamalarının fazla olması üç üniversite için de istatistiksel açıdan anlamlı değildir (p>0.05) (Ek 2, Ek 3, Ek 4). Kızların uzamsal zeka puan ortalamalarının fazla olması da üç üniversite için de istatistiksel açıdan anlamlı değildir (p>0.05) (Ek 2, Ek 3, Ek 4). Kızların müziksel zeka puan ortalamalarının fazla olması ise YTÜ ve MSGSÜ için istatistiksel açıdan anlamlı iken $(\mathrm{p}<0.05)(\mathrm{Ek} 3, \mathrm{Ek} 4)$, FSMVÜ için istatistiksel açıdan anlamlı değildir ( $\mathrm{p}>0.05)($ Ek 2).

Aygül ${ }^{45}$ de, "Tunceli Üniversitesi Meslek Yüksekokulu Öğrencilerinin Çoklu Zeka Alanları ile Öğrenme Stillerinin İncelenmesi” adlı yüksek lisans çalışmasında, veri toplama aracı olarak, Saban ${ }^{46}$ tarafindan çevirisi yapılan, Armstrong'un

45 İlkay Aygül, “Tunceli Üniversitesi Meslek Yüksekokulu Öğrencilerinin Çoklu Zeka Alanları ile Öğrenme Stillerinin İncelenmesi”, (Yayımlanmamış Yüksek Lisans Tezi), Cumhuriyet Üniversitesi Eğitim Bilimleri Enstitüsü Eğitim Bilimleri Ana Bilim Dalı, Sivas, 2015, s.60.

46 Ahmet Saban, Çoklu Zeka Teorisi ve Eğitim, Ankara, Nobel Yayın ve Dağıtım, 2002. 
eğitimciler için çoklu zeka alanları envanterini kullanarak, öğrencilerin müzikselritmik zekalarına ilişkin puanlarını cinsiyete göre karşılaştırmış ve kızların müziksel-ritmik zekaya ilişkin puan ortalamalarının erkek öğrencilerin ortalamalarından daha yüksek olduğu sonucuna ulaşmıştır ${ }^{47}$.

Özetle; yapılan bu çalışma, FSMVÜ, YTÜ ve MSGSÜ Mimarlık bölümlerinde sırasıyla Mimari Anlatım Dili, Mimari Anlatım Teknikleri ve Mimari Teknik Resim derslerini alan öğrencilerin çoklu zeka alanları ve çoklu zeka alanlarının cinsiyete göre nasıl farklılaştığını incelemektedir. Ancak, yapılan bu çalışma sadece üç üniversitedeki Mimarlık bölümlerinde Mimari Anlatım Dili, Mimari Anlatım Teknikleri ve Mimari Teknik Resim derslerini alan öğrencilerle sınırlı kaldığından çoklu zekayla ilgili yapılacak benzer çalışmalarda daha fazla mimarlık fakültesi ve farklı sınıf düzeylerindeki mimarlık öğrencilerinin zeka türleri incelenebilir. Ayrıca, mimarlık eğitimi için önem arz eden uzamsal zekanın alt bileşenleri olan "uzamsal görselleştirme, zihinde döndürme ve zihinde kesme" 48 yetenekleri mimarlık öğrencileri üzerinde detaylı olarak incelenebilir.

47 Aygül, a.g.e., s.79.

48 Nazan Sezen Yüksel, "Uzamsal Yetenek, Bileşenleri ve Uzamsal Yeteneğin Geliştirilmesi Üzerine”, (Yayımlanmamış Doktora Tezi), Hacettepe Üniversitesi Ortaöğretim Fen ve Matematik Alanlar Eğitimi Anabilim Dalı, Ankara, 2013, s.13-22. 


\section{Kaynakça}

Altan, Mustafa Zülküf, "Çoklu Zeka Kuramı ve Değerler Eğitimi”, Pegem Ĕ̈itim ve Ögrretim Dergisi, cilt 1, say1 4, 2011.

Armstrong, Thomas, Multiple Intelligences In The Classroom, Alexandria, Virginia, ASCD, 2000.

Aygül, İlkay, "Tunceli Üniversitesi Meslek Yüksekokulu Öğrencilerinin Çoklu Zeka Alanları ile Öğrenme Stillerinin İncelenmesi”, (Yayımlanmamış Yüksek Lisans Tezi), Cumhuriyet Üniversitesi Eğitim Bilimleri Enstitüsü Eğitim Bilimleri Ana Bilim Dal1, Sivas, 2015.

Başaran, Ilgın, "Etkili Öğrenme ve Çoklu Zeka Kuramı: Bir İnceleme”, Ege Ĕgitim Dergisi, 5, 2004.

Campbell, Linda - Campbell, Bruce - Dickinson, Dee, Teaching and Learning Through Multiple Intelligences, Massachusetts, Allyn \& Bacon, 1999.

Demirel, Erkan T. - Düşükcan, Muhammet - Ölmez, Mehmet, "Çoklu Zeka Alanlarının Girişimcilik Davranışına Etkisi”, Organizasyon ve Yönetim Bilimleri Dergisi, cilt 3, say1 2, 2011.

D’Souza, Newton, “Design Intelligences: A Case For Multiple Intelligences In Architectural Design", Archnet-International of Architectural Design, volume, issue 2, July 2007.

Gardner, Howard, The Unschooled Mind: How Children Think\&How Schools Should Teach, New York, Basic Books Published, 1991.

, Çoklu Zeka Kuramı: Zihin Çerçeveleri, çeviri Ebru Kılıç, 2. bs., Alfa Yayınları, 2010.

, Çoklu Zeka Yeni Ufuklar, Optimist Yayınları, 2013.

İflazoğlu, Ayten, "Çoklu Zeka Kuramı Destekli Kubaşık Öğrenme Yönteminin İlköğretim 5. Sınıf Öğrencilerinin Fen Bilgisi Dersindeki Akademik Başar1ları ve Tutumlarına Etkisi”, (Yayımlanmamış Doktora Tezi), Çukurova Üniversitesi, Adana, 2003.

İflazoğlu Saban, Ayten - Shearer, Branton - Kayıran, Bilge Kuşdemir - Işık, Dilek, "The Validity and Reliability Study of Turkish Version of the Multiple Intelligences Developmental Assessment Scales", International Journal Of Human Sciences, volume 9, issue 2, 2012.

Karabay, Ayşegül - Işık, Dilek - Bilaloğlu, Raziye Günay - Kayıran, Bilge Kuşdemir, "Çoklu Zeka Kuramı Temelli Çalışmaların Değerlendirilmesi: Türkiye Örneği”, Ç. Ü. Sosyal Bilimler Enstitüsü Dergisi, cilt 20, sayı 2, 2011. 
Kırmızı, Fatma Susar, “İlköğretim 4. Sınıf Türkçe Öğretiminde Çoklu Zeka Kuramına Dayalı İşbirlikli Öğrenme Yönteminin Erişi, Tutumlar, Öğrenme Stratejileri ve Çoklu Zeka Alanları Üzerindeki Etkileri”, (Yayımlanmamış Doktora Tezi), Dokuz Eylül Üniversitesi Eğitim Bilimleri Enstitüsü, İzmir, 2006.

Mendi, Faruk - Toktaş, İhsan - Karabıyık, Ömer, "Tasarı Geometride Görünürlük Prensiplerinin Bilgisayar Destekli Öğretimi”, Makine Teknolojileri Elektronik Dergisi, say1 3, 2004.

Nalçakan, Hande - Polatoğlu, Çiğdem, “Türkiye'deki ve Dünyadaki Mimarlık Eğitiminin Karşılaştırmalı Analizi İle Küreselleşmenin Mimarlık Eğitimine Etkisinin İrdelenmesi”, Megaron, YTÜ Mim. Fak. E-Dergisi, cilt 3, say1 1, 2008.

Saban, Ahmet, Çoklu Zeka Teorisi ve Eğitim, Ankara, Nobel Yayın ve Dağıtım, 2002. Ankara, Nobel Yayın, 2010.

, Çoklu Zeka Kuramı ve Türk Ĕ̈itim Sistemine Yansıması, 6. bs.,

Sağıroğlu, Pınar Meliha, "Mimari Tasarım Eğitiminde Çoklu Zeka Kuramından, Lefebre'nin Üçlü Mekan Diyalektiğine Uzanan Bir Öğrenme Deneyimi: Mekan Oyunları", Megaron, YTÜ Mim. Fak. E-Dergisi, cilt 12, sayı 1, 2017.

Shearer, Branton, The MIDAS: A Professional Manual, 1996.

Tarman, Süleyman, "Program Geliştirme Sürecinde Çoklu Zeka Kuramının Yeri”, (Yayımlanmamış Yüksek Lisans Tezi), Hacettepe Üniversitesi Sosyal Bilimler Enstitüsü, Ankara, 1999.

Turan, İbrahim - Şimşek, Ümit - Aslan, Hasan, "Eğitim Araştırmalarında Likert Ölçeği ve Likert-Tipi Soruların Kullanımı ve Analizi”, Sakarya Üniversitesi Eğitim Fakültesi Dergisi, 30, 2015.

Yeşilkaya, Özge Çongur, "Müzik Öğretiminde Çoklu Zeka Kuramı Uygulamalarına Yönelik Model Araştırma", (Yayımlanmamış Doktora Tezi), Gazi Üniversitesi, Ankara, 2007.

Yıldız, Doğan - Uzunsakal, Ece, "Alan Araştırmalarında Güvenilirlik Testlerinin Karşılaştırılması ve Tarımsal Veriler Üzerine Bir Uygulama”, Uygulamalı Sosyal Bilimler Dergisi, sayı 1, 2018.

Yüksel, Nazan Sezen, "Uzamsal Yetenek, Bileşenleri ve Uzamsal Yeteneğin Geliştirilmesi Üzerine”, (Yayımlanmamış Doktora Tezi), Hacettepe Üniversitesi Ortaöğretim Fen ve Matematik Alanlar Eğitimi Anabilim Dalı, Ankara, 2013. 


\section{Ekler}

Ek 1. Cinsiyet değişkenine göre zeka puanları arasında yapılan bağımsız örneklemler t-testi sonuçları

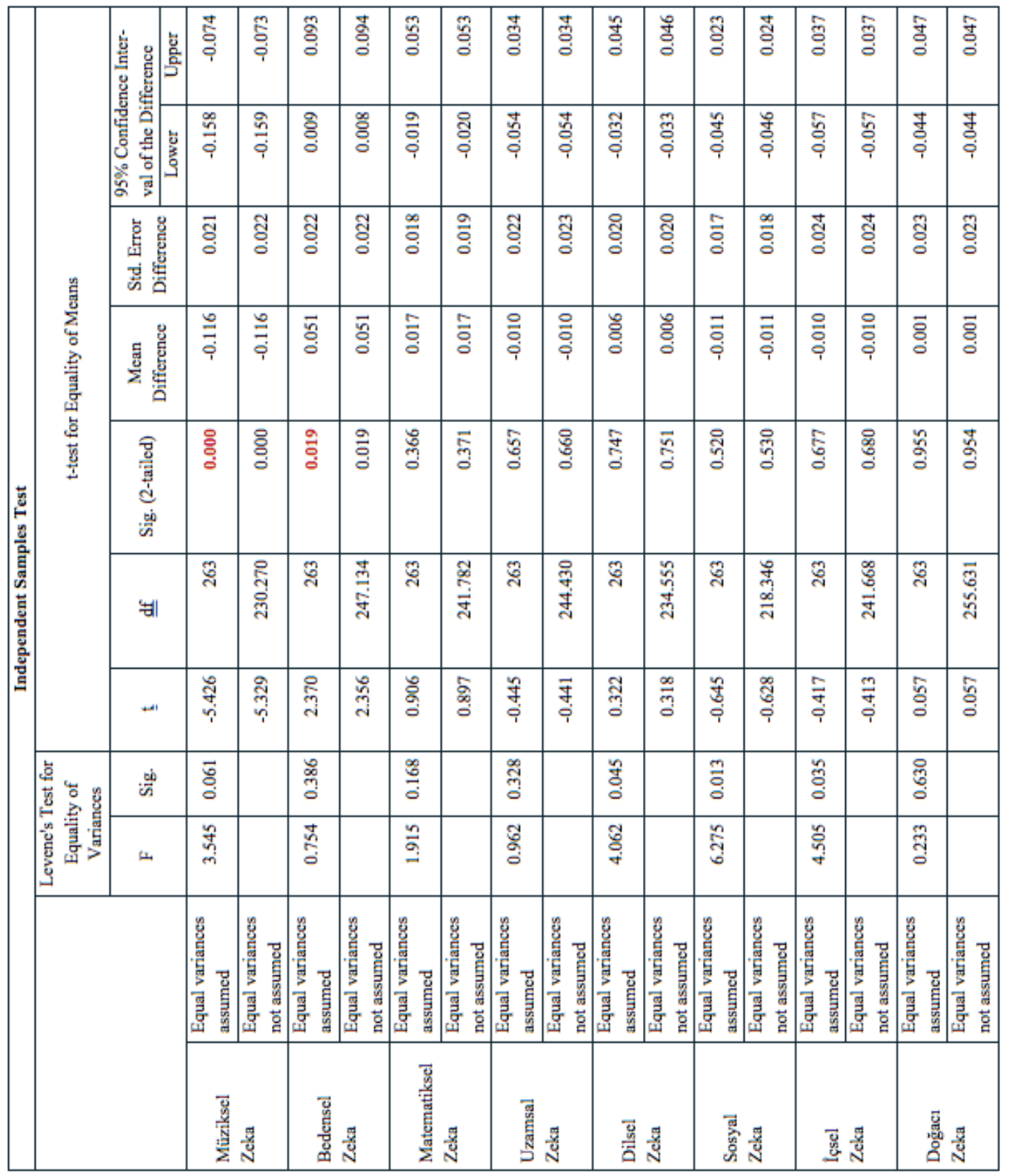


Ek 2. FSMVÜ öğrencilerinin cinsiyete göre çoklu zeka alanları bağımsız örneklemler t- testi sonuçları

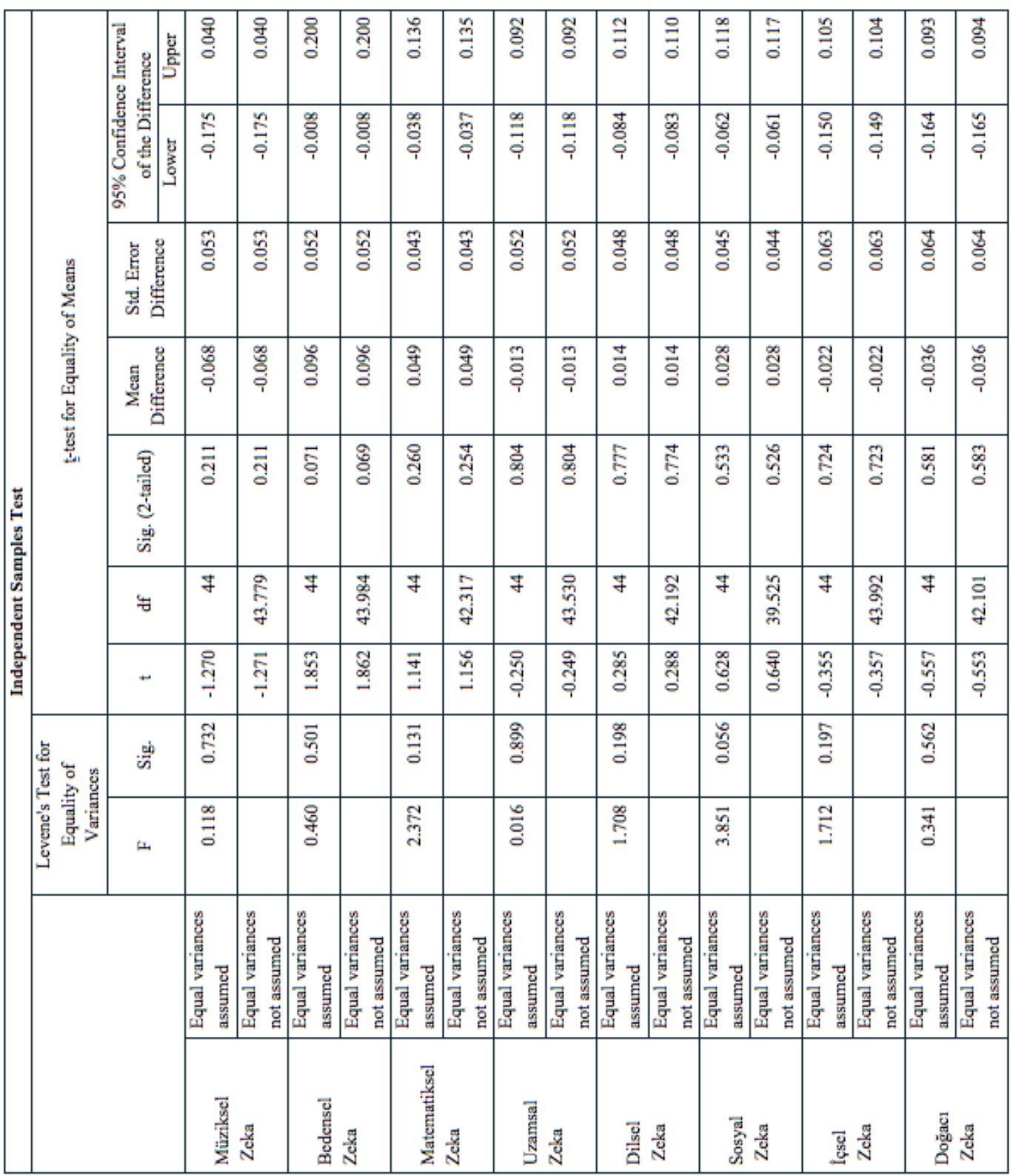


Ek 3. YTÜ öğrencilerinin cinsiyete göre çoklu zeka alanları bağımsız örneklemler t-testi sonuçları

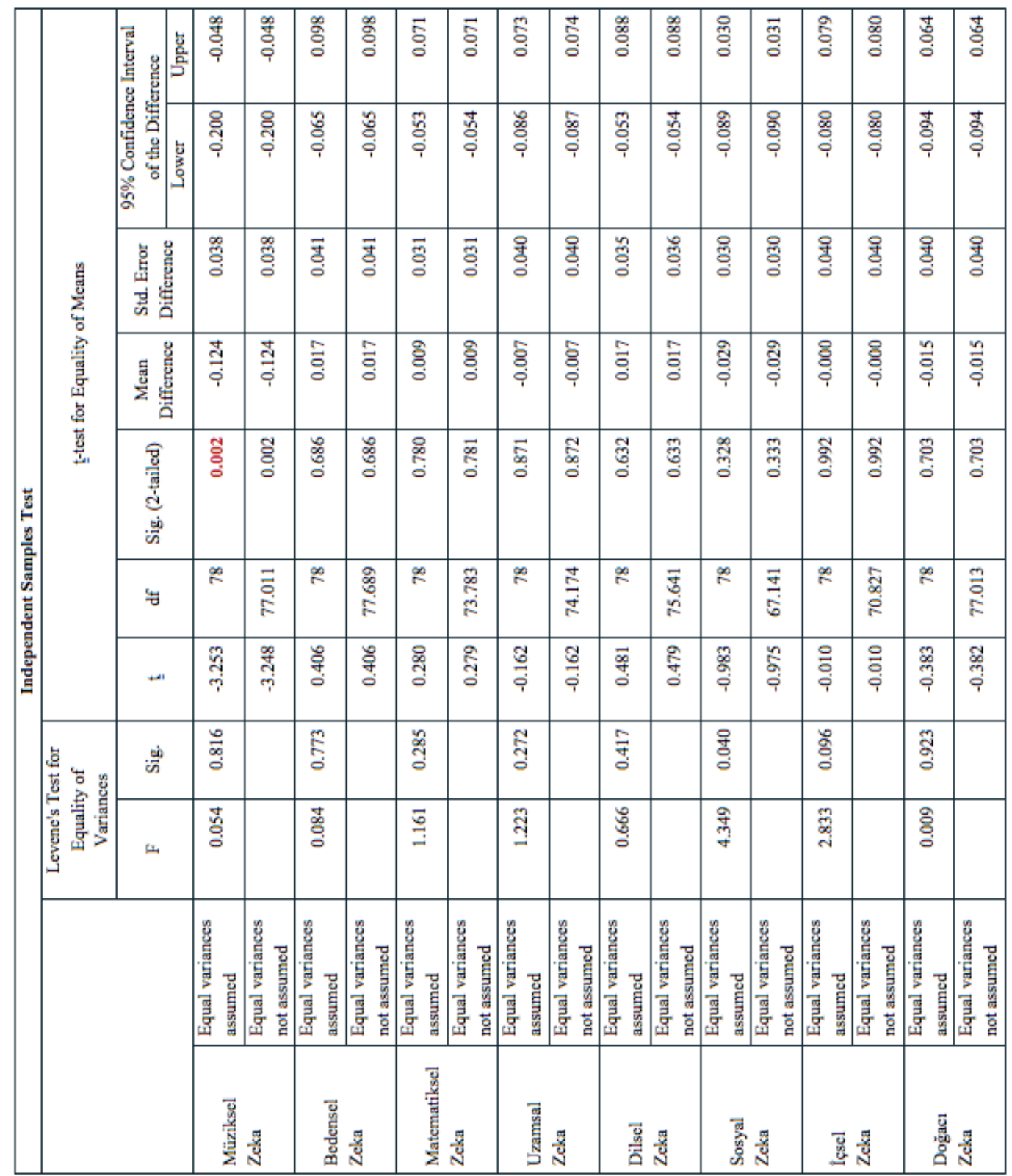


Ek 4. MSGSÜ öğrencilerinin cinsiyete göre çoklu zeka alanları bağımsız örneklemler t-testi sonuçları

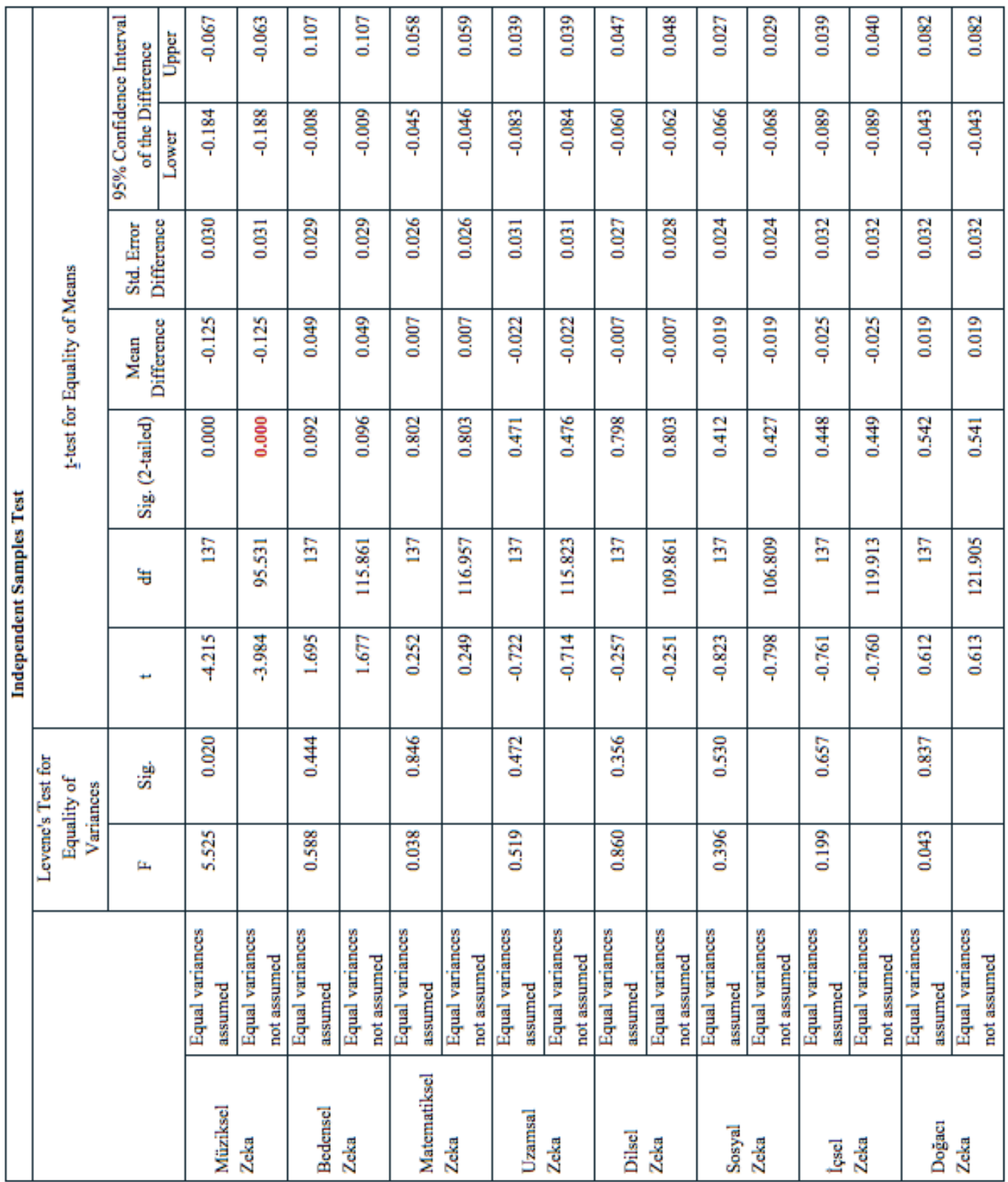

